\title{
Article
}

\section{Resveratrol Modulation of Apoptosis and Cell Cycle Response to Cisplatin in Head and Neck Cancer Cell Lines}

\author{
Marinela Bostan ${ }^{1,2}$, Mirela Mihaila ${ }^{1}$, Georgiana Gabriela Petrica-Matei ${ }^{3}{ }^{(}$, Nicoleta Radu ${ }^{4,5}, * \mathbb{C}$, \\ Razvan Hainarosie ${ }^{6}$, Cristian Dragos Stefanescu ${ }^{6}$, Viviana Roman ${ }^{1, *(1)}$ and Carmen Cristina Diaconu 7 (1) \\ 1 Center of Immunology, Stefan S. Nicolau Institute of Virology, 030304 Bucharest, Romania; \\ marinela.bostan@virology.ro (M.B.); mirela.mihaila@virology.ro (M.M.) \\ 2 Department of Immunology, Victor Babes National Institute of Pathology, 050096 Bucharest, Romania \\ 3 Personal Genetics-Medical Genetics Center, Department of Cytogenetics, 010987 Bucharest, Romania; \\ gabryela.matei@gmail.com \\ 4 Department of Biotechnology, University of Agronomic Sciences and Veterinary Medicine of Bucharest, \\ 011464 Bucharest, Romania \\ 5 Biotechnology Department, National Institute for Chemistry and Petrochemistry R\&D of Bucharest, \\ 060021 Bucharest, Romania \\ 6 Otorhinolaryngology and Head and Neck Surgery Department-Carol Davila University of Medicine and \\ Pharmacy, 020021 Bucharest, Romania; razvan@riaclinic.com (R.H.); dragos.stefanescu@umfcd.ro (C.D.S.) \\ 7 Department of Cellular and Molecular Pathology, Stefan S. Nicolau Institute of Virology, \\ 030304 Bucharest, Romania; directie@virology.ro \\ * Correspondence: nicoleta.radu@biotehnologii.usamv.ro (N.R.); viviana.roman@virology.ro (V.R.)
}

check for updates

Citation: Bostan, M.; Mihaila, M.; Petrica-Matei, G.G.; Radu, N.;

Hainarosie, R.; Stefanescu, C.D.;

Roman, V.; Diaconu, C.C. Resveratrol

Modulation of Apoptosis and Cell Cycle Response to Cisplatin in Head and Neck Cancer Cell Lines. Int. J. Mol. Sci. 2021, 22, 6322. https:// doi.org/10.3390/ijms22126322

Academic Editor: Amélia M. Silva

Received: 20 May 2021

Accepted: 8 June 2021

Published: 12 June 2021

Publisher's Note: MDPI stays neutral with regard to jurisdictional claims in published maps and institutional affiliations.

Copyright: (c) 2021 by the authors. Licensee MDPI, Basel, Switzerland. This article is an open access article distributed under the terms and conditions of the Creative Commons Attribution (CC BY) license (https:// creativecommons.org/licenses/by/ $4.0 /)$.

\begin{abstract}
In head and neck cancers, the effectiveness of cisplatin (CisPt) treatment is limited by its toxicity, especially when higher doses are necessary, and the possible occurrence of cisplatin resistance. This study evaluated the effects of resveratrol (RSV) on the expression of different genes involved in the response of human tumor cells (FaDu, PE/CA-PJ49) to cisplatin therapy. Our results revealed that RSV induced apoptosis amplification in both FaDu and PE/CA-PJ49 cells and modulated the expression of specific genes differently than in normal HaCaT cells. In FaDu cells, combined CisPt + RSV treatment induced an increase in apoptosis, which was associated with an increase in $c-M Y C$ and TP53 and a decrease in BCL-2 expression. While CisPt + RSV treatment induced apoptosis in PE/CA-PJ49 cells by inhibition of $B C L-2$ associated with high levels of $M D M-2$ and subsequently led to inhibition of TP53 gene expression. Decreased $c-M Y C$ expression in PE/CA-PJ49 treated with CisPt + RSV was accompanied by cell cycle blockage in G0/G1 phase. In conclusion, RSV influences tumor cell response to CisPt by inducing apoptosis and modulating gene expression. In addition, in normal HaCaT cells, RSV was able to reduce the harmful effects of CisPt.
\end{abstract}

Keywords: resveratrol; cisplatin; head and neck carcinoma line; $c-M Y C$; BCL-2; TP53; MDM-2; cell cycle; apoptosis

\section{Introduction}

On a global level, cancer was and remains to this day a serious matter of public health. It is a complex, multifactorial disease and, despite the evolution of radiotherapy and chemotherapy, there still is no significant progress regarding its treatment. Human head and neck squamous cell carcinoma (HNSCC) is an aggressive type of cancer that develops from epithelial cells. HNSCC is characterized by rapid progression and metastases associated with a poor prognosis [1]. For this type of cancer, chemotherapy is a method to reduce the tumor's mass before surgery and to prevent metastases afterward. For patients diagnosed in advanced stages of HNSCC that are declared inoperable, chemotherapy remains one of the few therapeutic options. Thus, how tumoral cells respond to chemotherapeutic agents and the methods through which chemotherapy sensibility can be increased represent a major interest both for research as well as for clinical approach [2-4]. Conventional 
therapies for HNSCC consist of treatment with CisPt, which is frequently accompanied by severe adverse reactions, such as nephrotoxicity, ototoxicity, hematologic toxicity, or central nervous system afflictions, that eventually will lead to stopping the treatment [5-7]. CisPt diffuses passively through the cellular membrane and is activated in the cellular environment, becoming a strong electrophile, capable of reacting with some of the nucleophilic sites found in the nucleic acids. These reactions between the platinum atom of CisPt and the purine bases found within the DNA lead to the formation of intra-strand and inter-strand covalent bonds [8,9]. These processes allow the formation of CisPt-DNA adducts, which interfere with DNA replication and transcription [10]. Additionally, the interactions between CisPt and some proteins considered to be sulfur donors (such as cysteine, methionine, thiols, etc.) have been described, therefore allowing an understanding of how CisPt enters the cell and interacts with different cellular structures, thus leading to a better understanding of the action mechanism of CisPt and dose efficiency [11,12].

Moreover, this information opens the path for new approaches regarding combined therapies that use different adjuvants with either a protective role or a synergistic antitumoral role. When CisPt induces an advanced degree of deterioration of the DNA, the reparatory capacity of the cells is exceeded and then the cell, through the activation of some specific signaling pathways, enters the stage of programmed cell death, also known as apoptosis $[13,14]$. Understanding the cytotoxic mechanisms induced by CisPt allows a more precise approach to antitumoral therapies and better management of their efficiency by using natural compounds that can enhance the effects of $\mathrm{CisPt}$, while also reducing its toxicity within the normal cells. In order to reduce the number of chemotherapeutic drug adverse reactions and their magnitude, some natural compounds have been used as adjuvants for chemotherapeutic agents in different in vitro studies and also in many clinical trials [15-18].

Natural compounds have been used to obtain new drugs, or they have been used for the improvement of the therapeutic scheme in different illnesses in combination with chemotherapeutic drugs. One of the most studied natural compounds is RSV, due to its antioxidant, antitumoral, and anti-inflammatory properties [19-22]. RSV has drawn significant attention from scientists, as it is capable of suppressing the proliferation of tumoral cells, inducing apoptosis, or of sensitizing tumoral cells to the effects of radioand chemotherapy [23-28]. RSV is a polyphenolic phytoalexin that is found in red fruits, peanuts, and grapes and presents antimicrobial, antioxidant, cardioprotective, and antitumoral properties, a fact that is supported by various in vivo and in vitro studies conducted on a variety of types of cancer such as colon, pancreatic, breast, liver, prostate, or lung cancer [29-32]. Numerous studies have shown that RSV has a role in modulating the intracellular molecular processes involved in stopping the cell cycle or in apoptosis in different types of cancer, including HNSCC [33-37].

Some genes have an important role in the appearance and evolution of tumoral cells, genes that are involved in signal transduction pathways and thus can control the cellular processes, such as proliferation, cell cycle, and apoptosis induction [38-41]. Apoptosis, also known as programmed cell death, is a process used to eliminate deteriorated or abnormal cells through alterations of the cellular membrane, cellular contraction, nuclear DNA fragmentation, and apoptotic bodies. Disruption in the regulation of apoptosis is crucial in the development of the tumor and genes such as TP53, MDM-2, Bcl-2, and C-MYC play a major role in the process of controlling apoptosis [42-47].

A key mediator in preventing carcinogenesis is TP53, a tumoral suppressor gene strongly connected to the processes of transcription, proliferation, and apoptosis [48,49]. As an answer to DNA deterioration, MDM-2-a ubiquitin ligase E3 - can reduce cellular proliferation and can activate apoptosis by targeting TP53. MDM-2 and TP53 are both important players involved in DNA damage repair [50-53]. Another important role in cellular proliferation, cell cycle, apoptotic process, and also in the response to therapy is apparently held by $c-M Y C$, a nuclear transcription factor. Data published in different studies regarding the functions of $c-M Y C$ in different malignant tumors are extremely 
controversial [54-59]. C-MYC seems to be involved in the activation of cellular proliferation, as well as in triggering the apoptotic process, without researchers knowing exactly what is determining this dual behavior. Some studies have shown that the B-cell lymphoma gene $(B C L-2)$ is overexpressed and has a role in the development of cytostatic resistance in tumoral cells [60-63].

The $c-M Y C$ gene could cooperate with other oncogenes such as $B C L-2$, and thus it might influence the mechanisms involved in tumor surveillance. Therefore, targeted therapy against $B C L-2$ can enhance the antitumoral effects of chemotherapy by tumoral cell sensitization in order to cause them to enter apoptosis. This study analyzed how RSV treatment alone or in combination with CisPt influences the expression of these genes, as well as the manner in which cellular processes such as the cell cycle, proliferation, and apoptosis of tumoral cells can be modulated. To acquire useful information that could lead to a more efficient therapeutic approach in head and neck cancers, we analyzed the effect of RSV treatment on the response induced by CisPt in FaDu and PE-CA/PJ49 tumoral cell lines. The HaCaT cell line was used in order to analyze the effect of the treatment with RSV and/or CisPt on a normal cell line. The cells were treated both separately and in combination with RSV and/or CisPt, and the effect on the expression of the genes (c-MYC, $B C L-2, M D M-2$, and TP53) with a role in the proliferation process, the evolution of the cell cycle, and the activation of the apoptotic process was analyzed. Emphasizing the role of RSV in the modulation of the effect induced by CisPt on the expression of the above mentioned genes could lead to a better understanding of how a cell engages in either the proliferation process or in apoptosis. All the previously mentioned aspects may contribute to the opening of more efficient therapeutic approaches for head and neck cancer.

\section{Results}

\subsection{RSV Effects on the Proliferation of Head and Neck Tumor Cells Treated with CisPt}

We compared the inhibitory effects of RSV and/or CisPt on the proliferation of PE/CAPJ49, FaDu tumor adherent cells versus HaCaT-normal adherent cells-using the 3-(4,5dimethylthiazol-2-yl)-2,5- diphenyltetrazolium bromide (MTT) assay. To select the optimal working concentrations, the tumor and normal cells were treated for 24,48 , and $72 \mathrm{~h}$ with $\mathrm{RSV}$ or CisPt in concentrations ranging between 2 and $256 \mu \mathrm{M}$. The drug response curve was generated, and IC50 (the concentration required to kill $50 \%$ of the cell population) was calculated using GraphPad Prism version 7.00 [64,65]. Data obtained when treating the cells with RSV or Cis for 48 or $72 \mathrm{~h}$ did not differ significantly compared to the values obtained at $24 \mathrm{~h}$ (Table 1$)$.

Table 1. IC50 (inhibitory concentration) values of the cisplatin and resveratrol were determined using a linear regression equation for the cytotoxicity curve for PE/CA-PJ49, FaDu tumor cells and for $\mathrm{HaCaT}$ normal cells. IC50 values are presented as mean \pm SEM according to two independent assays, each done in triplicate. The Selectivity Index (SI) = IC50 of a compound in a normal cell line/IC50 of the same compound in a cancer cell line. SI values of more than 2 were considered as high selectivity.

\begin{tabular}{cccccc}
\hline & \multicolumn{3}{c}{ IC50 } & \multicolumn{2}{c}{ SI } \\
\hline 24 h Treatment & HaCaT & PE/CA-PJ49 & FaDu & HaCaT/PE/CA-PJ49 & HaCaT/FaDu \\
\hline CisPt $(\mu \mathrm{M})$ & $23.9+/-1.6$ & $9.1+/-2.1$ & $12.1+/-1.9$ & 2.63 & 1.97 \\
\hline RSV $(\mu \mathrm{M})$ & $94.7+/-2.9$ & $44.9+/-3.1$ & $39.3+/-1.9$ & 2.15 & 2.41 \\
\hline
\end{tabular}

To establish the degree of selectivity of the CisPt or RSV after $24 \mathrm{~h}$ treatment we used the IC50 value in order to calculate the selectivity index (SI). SI indicates the cytotoxic selectivity for CisPt or RSV against cancer cells versus normal cells (Table 1) [66,67]. To minimize the toxic effect of CisPt on normal cells and keep them in accord with selectivity index values we selected the working concentration of $10 \mu \mathrm{M}$ CisPt and $50 \mu \mathrm{M}$ RSV and the optimal treatment time of $24 \mathrm{~h}$. 
As seen in Table 1, the response of tumor cells to CisPt or RSV treatment was different and dependent on agent concentration compared to the response of normal cells. The SI values obtained showed that PJ49 PE/CA tumor cells $(\mathrm{SI}=2.63)$ had a higher selectivity for CisPt treatment than FaDu tumor cells (SI = 1.97). In the case of RSV treatment, both tumor lines had high selectivity, the registered SI being higher than 2 .

To determine how the $10 \mu \mathrm{M}$ CisPt or $50 \mu \mathrm{M}$ RSV treatment alone or in combination for $24 \mathrm{~h}$ influenced the proliferation process of the tumor and normal cells we analyzed the growth rate of the cells using the proliferation kit described in Section 4, Materials and Methods.

The index of proliferation (IP) data obtained when treating the cells for 48 or $72 \mathrm{~h}$ did not differ significantly compared to the IP values obtained at $24 \mathrm{~h}$. For this reason, all experiments in our study were performed using concentrations of $50 \mu \mathrm{M}$ RSV and/or $10 \mu \mathrm{M}$ CisPt for $24 \mathrm{~h}$.

As seen in Table 2 and Figure 1, treatment with $10 \mu \mathrm{M}$ CisPt for $24 \mathrm{~h}$ reduced the proliferation of PE/CA-PJ49 (IP $=0.55 ; p<0.00008,{ }^{* * * *}$ ), FaDu tumor cells (IP $=0.71$; $p<0.00051, * * *)$ and greatly affected the proliferative process in normal HaCaT cells $\left(\mathrm{IP}=0.67 ; p<0.00063,{ }^{* * *}\right)$ compared to untreated cells (Control, IP $\left.=1\right)$. The results showed that PE/CA-PJ49 tumor cells respond differently to $10 \mu \mathrm{M}$ CisPt treatment when compared to FaDu tumor cells $\left(p<0.05 ;{ }^{*}\right)$. A treatment of $50 \mu \mathrm{M}$ RSV for $24 \mathrm{~h}$ affected the proliferation of FaDu tumor cells (IP $=0.54 ; p<0.00018,{ }^{* * *}$ ) more than it did the PE/CA-PJ49 tumor cells (IP $\left.=0.65, p<0.00275,{ }^{* *}\right)$ and had less influence on the proliferative process of normal $\mathrm{HaCaT}$ cells $\left(\mathrm{IP}=0.83, p<0.0022,{ }^{* *}\right)$ compared to untreated cells (control, IP $\left.=1\right)($ Table 2 and Figure 1).

Table 2. The index of proliferation (IP) for tumor cell line PE/CA-PJ49, FaDu, and normal cell line HaCaT treated with RSV and/or CisPt for 24, 48, and $72 \mathrm{~h}$. IP is equal to absorbance of treated cells/absorbance of untreated cells. Results are expressed as mean values of three determinations \pm standard deviation (SD). Untreated cells serve as control and are considered to have the index of proliferation (IP) equal to 1 .

\begin{tabular}{ccccccccccc}
\hline \multirow{2}{*}{ Treatment/Cell Lines } & \multicolumn{3}{c}{ HaCaT } & \multicolumn{4}{c}{ PE/CA-PJ49 } & \multicolumn{3}{c}{ FaDu } \\
\cline { 2 - 10 } & $\mathbf{2 4} \mathbf{~ h}$ & $\mathbf{4 8} \mathbf{~ h}$ & $\mathbf{7 2} \mathbf{~ h}$ & $\mathbf{2 4} \mathbf{~ h}$ & $\mathbf{4 8} \mathbf{~ h}$ & $\mathbf{7 2} \mathbf{~ h}$ & $\mathbf{2 4} \mathbf{~ h}$ & $\mathbf{4 8 ~ h}$ & $\mathbf{7 2} \mathbf{~ h}$ \\
\hline $10 \mu \mathrm{M}$ CisPt & 0.52 & 0.35 & 0.56 & 0.55 & 0.53 & 0.50 & 0.67 & 0.55 & 0.51 \\
\hline $50 \mu \mathrm{M} \mathrm{RSV}$ & 0.79 & 0.42 & 0.81 & 0.68 & 0.64 & 0.60 & 0.53 & 0.49 & 0.57 \\
\hline $10 \mu \mathrm{M} \mathrm{CisPt}+50 \mu \mathrm{M}$ RSV & 0.74 & 0.68 & 0.70 & 0.43 & 0.48 & 0.52 & 0.59 & 0.53 & 0.51 \\
\hline
\end{tabular}

When the $10 \mu \mathrm{M}$ CisPt $+50 \mu \mathrm{M}$ RSV combined treatment was applied, a decrease of proliferation was observed in PE/CA-PJ49 tumor cells (IP = 0.43), the dominant effect on proliferation being exerted by CisPt $\left(p<0.011 ;{ }^{*}\right)$. In contrast, in the case of $\mathrm{FaDu}$ tumor cells $(\mathrm{IP}=0.59) \mathrm{CisPt}+\mathrm{RSV}$ combined treatment reduced proliferation in the same manner as RSV (IP $=0.54 ; p=\mathrm{ns}$ ) or CisPt (IP $=0.71 ; p=\mathrm{ns}$ ) alone (Figure 1, Table 2). In normal HaCaT cells, data obtained when the combined treatment was applied showed that RSV (IP $=0.83 ; p<0.029 ;{ }^{* *}$ ) appeared to protect cells from the toxic effect of CisPt (0.67) (Figure 1 and Table 2). As seen in Figure 1, the proliferation of PE/CA-PJ49 tumor cells compared to $\mathrm{FaDu}$ tumor cells was affected differently in the case of treatment only with CisPt $\left(p<0.025 ;{ }^{*}\right)$ or RSV $\left(p<0.044 ;^{*}\right)$ applied separately. Comparative analysis of the proliferative response of PE/CA-PJ49 $\left(p<0.00038,{ }^{* * *}\right)$ or FaDu $\left(p<0.004 ;{ }^{* *}\right)$ tumor cells versus the normal $\mathrm{HaCaT}$ cells to the combined CisPt $+\mathrm{RSV}$ treatment showed a significantly different cellular behavior. It can also be seen that the response of the two tumor cell lines, PE/CA-PJ49 and FaDu, to the CisPt + RSV combined treatment, was significantly different $\left(p<0.05 ;{ }^{*}\right)$. 


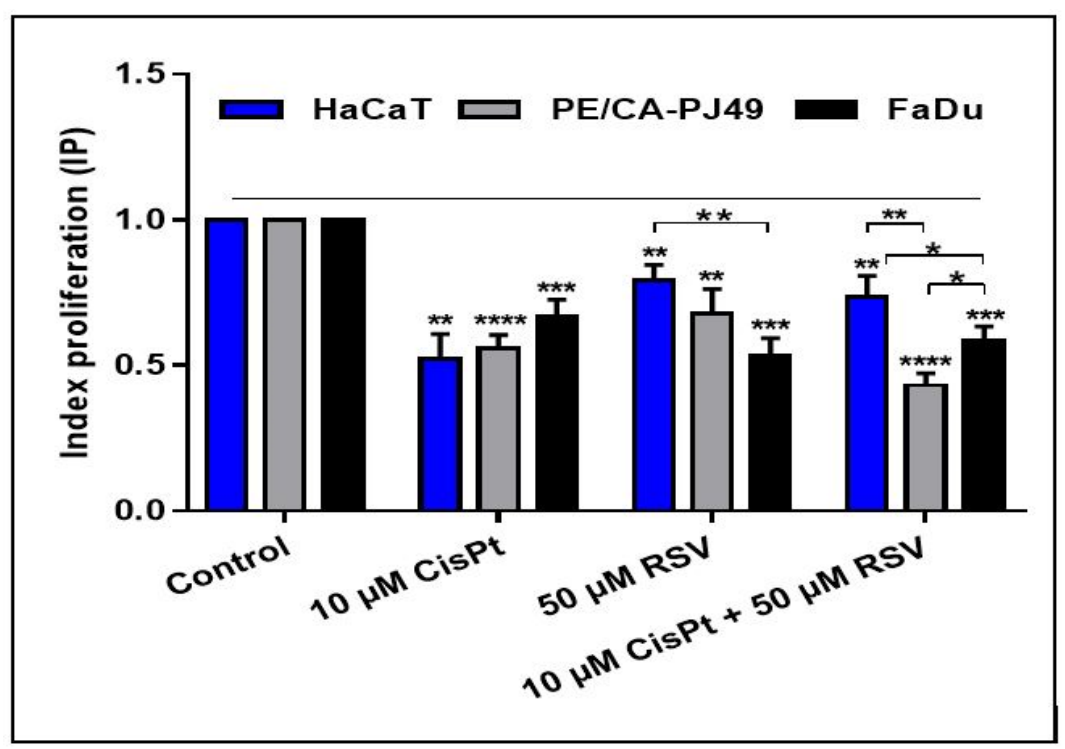

Figure 1. The index of proliferation (IP) for tumor cell line PE/CA-PJ49, FaDu and normal cell line $\mathrm{HaCaT}$ treated with RSV and/or CisPt for $24 \mathrm{~h}$. IP is equal to absorbance of treated cells/absorbance of untreated cells. Results are expressed as absorbance mean values of three determinations $+/-$ standard deviation (SD). Untreated cells are considered to have an IP equal 1. $\left({ }^{*} p<0.05,{ }^{* *} p<0.005\right.$, *** $\left.p<0.0005 ;{ }^{* * * *} p<0.00005\right)$.

\subsection{The RSV Effects on the Gene Expression of Head and Neck Tumor Cells Treated with CisPt}

\subsubsection{TP53 Gene Expression Analysis}

The action mechanism of cisplatin is not yet fully understood, its effects seem to be partially associated with the TP53 suppressor gene, which has an important role in cancers. In numerous types of cancer, head and neck cancer included, TP53 suffers mutations that could have a major impact on the pathology of the disease and its response to treatment. Data from literature support the fact that when TP53 suffers mutations, the illness becomes aggressive and resistant to ionizing radiation and even to chemotherapy, but there are also opposing opinions regarding the influence of TP53 mutations on the effectiveness of therapy with cisplatin $[68,69]$.

In order to obtain useful information on the most efficient therapeutic approach in head and neck cancers, we analyzed the effect of treatment with RSV on the response induced by CisPt treatment on FaDu tumor cells that have a point mutation of TP53 [70] compared to PE/CA-PJ49 tumor cells that have no mutations of the TP53 gene. The $\mathrm{HaCaT}$ cellular line was used to analyze the effect of treatment with RSV and/or CisPt on normal cells.

As shown in Figure 2A, treatment with CisPt $10 \mu \mathrm{M}$ did not significantly modify the expression of the TP53 gene in PE/CA-PJ49 tumor cells $(p=n s)$. In FaDu tumor cells, treatment with $10 \mu \mathrm{M}$ CisPt induced a significant growth of TP53 gene expression $\left(p<0.006,{ }^{* *}\right)$, compared to the untreated FaDu cells. The cellular response to CisPt treatment showed a significant increase in TP53 expression in FaDu cells $\left(p<0.007,{ }^{* *}\right)$ compared to PE/CA-PJ49 cells. In normal HaCaT cells, treatment with $10 \mu \mathrm{M}$ CisPt led to a decrease of the TP53 gene expression, compared to the FaDu tumor cells $\left(p<0.005,{ }^{* *}\right)$ (Figure 2A, Table 3). 


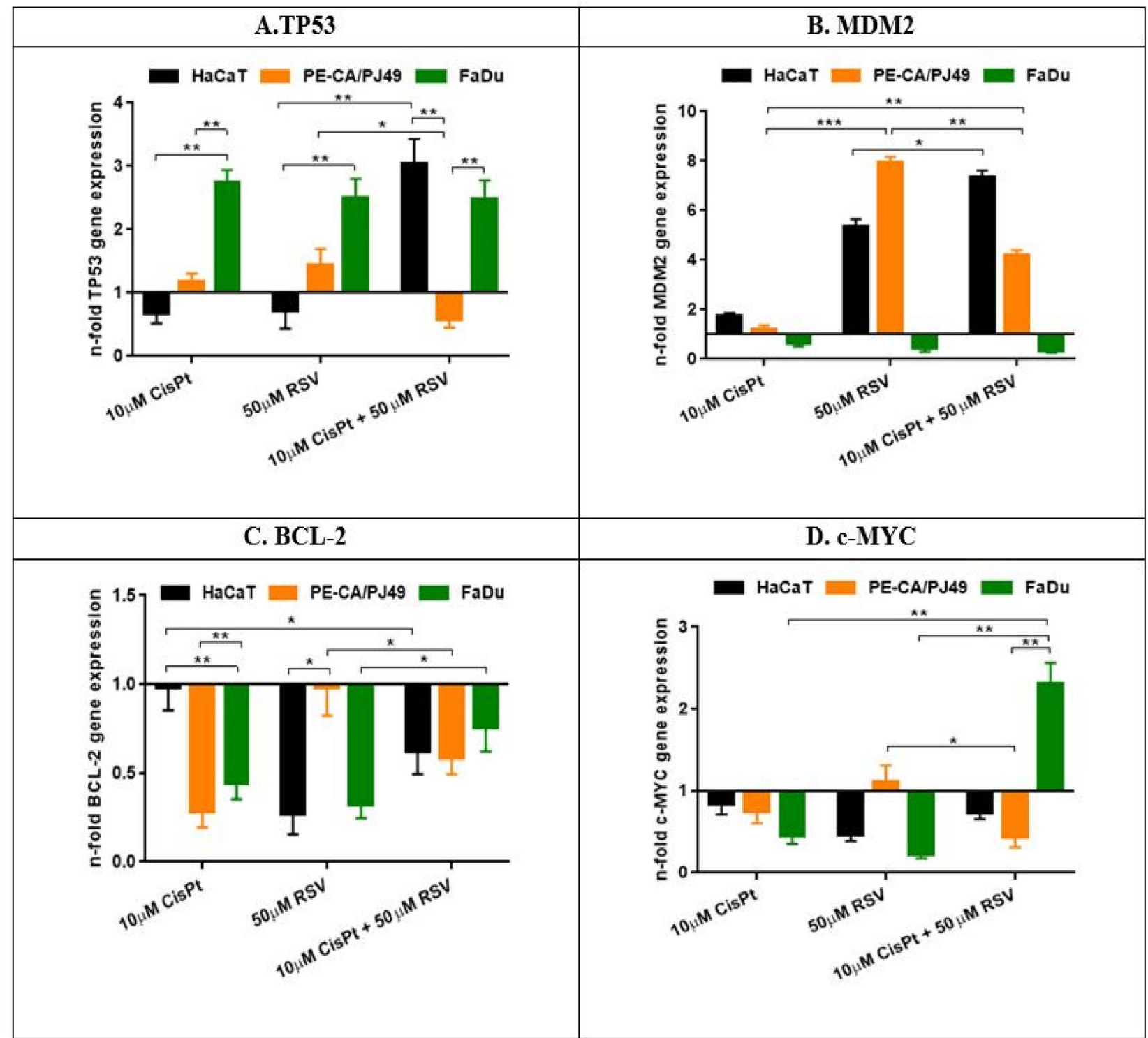

Figure 2. The effect of CisPt and/or RSV treatment on gene expression ((A) - TP53; (B)—MDM-2; (C) —BCL-2; (D)—C-MYC) in tumor cells PE/CA-PJ49 and FaDu compared to normal HaCaT cells. The results were obtained using gene reference HPRT (hypoxanthine phosphoribosyltransferase). Control is represented by the untreated cells of each cell line and the $\mathrm{n}$-fold expression for each gene analyzed in control cells is 1 . Each sample was performed in duplicate. The samples were analyzed using the formula $2-\Delta \Delta \mathrm{Ct}=$ gene expression. $\left({ }^{*} p<0.05,{ }^{* *} p<0.005,{ }^{* * *} p<0.0005\right)$.

Table 3. $n$-fold gene expression in PE-CA/PJ49 or FaDu tumor cells versus normal HaCaT cells treated for $24 \mathrm{~h}$ with $10 \mu \mathrm{M}$ CisPt and/or $50 \mu \mathrm{M}$ RSV. The results were obtained using gene reference HPRT. Control is represented by the untreated cells of each cell line, and the $n$-fold expression for each gene analyzed in control cells was 1.

\begin{tabular}{|c|c|c|c|c|c|c|c|c|c|}
\hline \multirow{2}{*}{$\begin{array}{c}\text { n-Fold Gene } \\
\text { Expression/ } \\
\text { Treatment }\end{array}$} & \multicolumn{3}{|c|}{ HaCaT } & \multicolumn{3}{|c|}{ PE/CA-PJ49 } & \multicolumn{3}{|c|}{ FaDu } \\
\hline & CisPt & RSV & $\underset{\text { RSV }}{\text { CisPt + }}$ & CisPt & RSV & $\begin{array}{c}\text { CisPt + } \\
\text { RSV }\end{array}$ & CisPt & RSV & $\begin{array}{c}\text { CisPt + } \\
\text { RSV }\end{array}$ \\
\hline TP53 & 0.69 & 0.82 & 3.05 & 1.18 & 1.44 & 0.59 & 2.7 & 2.5 & 2.4 \\
\hline MDM2 & 1.7 & 5.3 & 7.3 & 1.2 & 7.9 & 4.2 & 0.65 & 0.46 & 0.37 \\
\hline BCL2 & 0.98 & 0.27 & 0.62 & 0.29 & 0.96 & 0.59 & 0.46 & 0.33 & 0.17 \\
\hline c-MYC & 0.84 & 0.47 & 0.74 & 0.75 & 1.11 & 0.44 & 0.45 & 0.22 & 2.3 \\
\hline
\end{tabular}


The expression of the TP53 gene was not significantly affected by treatment with $50 \mu \mathrm{M}$ RSV in the normal HaCaT cells or PE/CA-PJ49 tumor cells. On the other hand, RSV induced a highly significant rise of TP53 gene expression in FaDu cells, compared to normal HaCaT cells $\left(p<0.009,{ }^{* *}\right)$ and PE/CA-PJ49 tumor cells $(p<0.05, *)$ (Figure 2A, Table 3).

In the case of the combined treatment RSV + CisPt the expression of the TP53 gene remained increased in $\mathrm{FaDu}$ cells, but without recording an additive effect of the two agents (Figure 2A). The combined treatment with RSV + CisPt on PE/CA-PJ49 tumor cells displayed a significant decrease of the TP53 expression, compared to FaDu tumor cells $\left(p<0.007,{ }^{* *}\right)$ and to HaCaT cells $\left(p<0.004,{ }^{* *}\right)$. The statistical analysis on the effect induced by simultaneous treatment with CisPt + RSV on PE/CA-PJ49 tumor cells, compared to the effects induced by CisPt $\left(p<0.05,{ }^{*}\right)$ or RSV $\left(p<0.04,{ }^{*}\right)$ separately, showed inhibition of TP53 expression (Figure 2A, Table 3).

Also, it was observed that combined treatment with CisPt + RSV enhanced the expression of TP53 in normal HaCaT cells, even though separately they both inhibited TP53 expression. The ANOVA analysis sustained the different ways in which the combined treatment with CisPt + RSV $\left(p<0.006,{ }^{* *}\right)$ modified the TP53 gene expression, compared to the effect induced separately by CisPt or RSV in HaCaT cells (Figure 2A, Table 3).

\subsection{2. $M D M-2$ Gene Expression Analysis}

The link between TP53 and MDM-2 is one of the most studied connections between a tumor suppressor gene and an oncogene, both being predisposed to mutations in head and neck cancers. Because the MDM-2 gene is known as a negative regulator of the TP53 gene, efforts have been made to establish a direct connection between treatment with $\mathrm{CisPt}$ and/or RSV and the level of expression of the two genes. Our study analyzed the effect induced by treatment with CisPt and/or RSV on the expression of the MDM-2 gene in tumor cells, and we tried to establish a possible link between the TP53 gene expression and the $M D M-2$ gene expression. The obtained results showed that treatment of FaDu cells with $10 \mu \mathrm{M}$ CisPt and/or $50 \mu \mathrm{M}$ RSV induced a slight inhibition of MDM-2 gene expression, compared to untreated cells (Figure 2B, Table 3).

The results obtained on PE/CA-PJ49 tumor cells treated for $24 \mathrm{~h}$ with $10 \mu \mathrm{M} \mathrm{CisPt}$ applied alone showed that $M D M-2$ gene expression was not modified compared to untreated cells, while $50 \mu \mathrm{M}$ RSV induced a significant increase of the $M D M-2$ gene expression $(p<0.0005, * * *)$, compared to the effect induced by CisPt. Additionally, it was observed that the combined treatment CisPt + RSV amplified the MDM-2 gene expression in PE/CAPJ49 tumor cells more than the effect induced by CisPt alone $\left(p<0.003,{ }^{* *}\right)$ or RSV alone $\left(p<0.004{ }^{* *}\right)$ (Figure 2B, Table 3).

Treatment with $50 \mu \mathrm{M}$ RSV $\left(p<0.0025,{ }^{* *}\right)$ applied alone on the HaCaT normal cell line induced a significant increase of $M D M-2$ gene expression compared to untreated cells (control) and caused a much bigger effect than that induced by treatment with $10 \mu \mathrm{M} \mathrm{CisPt}$ $\left(p<0.013,{ }^{*}\right)$ versus control (Figure 2B, Table 3$)$. The effect of CisPt + RSV treatment seems to increase $M D M-2$ gene expression, being significantly stronger compared to the effect induced by treatment with CisPt alone $\left(p<0.001,{ }^{* *}\right)$ (Figure 2B, Table 3).

\subsubsection{BCL-2 Gene Expression Analysis}

CisPt did not affect $B C L-2$ gene expression in HaCaT normal cells. Treatment with CisPt significantly reduced $B C L-2$ gene expression in $\mathrm{FaDu}\left(p<0.05,{ }^{*}\right)$ and PE/CA-PJ49 $(p<0.025, *)$ tumor cell lines compared to the effect induced on the HaCaT normal line (Figure 2C, Table 3).

As shown in Figure 2C, treatment with RSV acted similarly on FaDu tumor cells $(p<0.005, * *)$ and HaCaT cells $\left(p<0.006,{ }^{* *}\right)$, and it resulted in the inhibition of BCL-2 gene expression compared to untreated cells. RSV did not significantly modify $B C L-2$ gene expression in PE/CA-PJ49 tumor cells, the effect being different from the one induced in HaCaT cells $\left(p<0.035,{ }^{*}\right)$. Furthermore, by comparing the level of expression of the BCL-2 
gene in the two tumor lines, PE/CA-PJ49 and FaDu $(p<0.03, *)$, the different action mode of RSV was observed (Figure 2C, Table 3). The expression of the BCL-2 gene in FaDu tumor cells was less affected by combined treatment with CisPt $+\operatorname{RSV}\left(p<0.04,{ }^{*}\right)$, compared to the effect induced by RSV alone. In PE/CA-PJ49 tumor cells, combined treatment with CisPt + RSV $\left(p<0.05,{ }^{*}\right)$ decreased BCL-2 gene expression compared to the effect induced by RSV applied alone.

Thus, it was seen that the CisPt effect appeared to be dominant in the decreasing of $B C L-2$ expression when the combined treatment CisPt + RSV was applied. Analysis of $B C L-2$ gene expression in $\mathrm{HaCaT}$ normal cell line showed that the effect induced by the combined treatment CisPt $+\mathrm{RSV}$ was significantly different than the one with only CisPt $\left(p<0.03 ;{ }^{*}\right)$ (Figure $2 C$, Table 3 ). Comparative analysis of $B C L-2$ gene expression in PE/CA-PJ49 and FaDu cell lines showed that these tumor cells had a similar response to treatment with CisPt and to the combined treatment CisPt + RSV, but they reacted in a different way to treatment with RSV alone $\left(p<0.03,{ }^{*}\right)$.

\subsection{4. c-MYC Gene Expression Analysis}

$c-M Y C$ plays an important role in the progression of the cell cycle, apoptosis, and malignant transformation. The association of the $c-M Y C$ gene with tumor progression can partially be explained by its role in regulating the cell cycle, as it is a regulator of the cyclin-dependent kinases. An increased level of $c-M Y C$ expression has been observed in many different types of cancer, including HNSCC cancers [71,72]. It is known that $c-M Y C$ can participate in the process of tumor initiation, but it has not yet been discovered if it is involved in tumor progression or the response to therapy. The hypothesis of our study was to modulate the $c-M Y C$ gene expression through treatment with CisPt associated with a natural compound such as RSV.

Treatment with $10 \mu \mathrm{M}$ CisPt on a HaCaT normal cell line did not affect the $c-M Y C$ gene expression, but treatment with $50 \mu \mathrm{M}$ RSV $\left(p<0.01,{ }^{*}\right)$ reduced the gene's expression compared to the control. Also, the treatment of $\mathrm{HaCaT}$ cells with CisPt $+\mathrm{RSV}$ did not lead to significant changes in $c-M Y C$ gene expression (Figure 2D, Table 3). Treatment with $10 \mu \mathrm{M}$ CisPt resulted in a reduction of $c-M Y C$ gene expression in $\mathrm{FaDu}(p<0.01, *)$ and less in PE/CA-PJ49 tumor cells compared to the control (untreated cells) (Figure 2D, Table 3). RSV did not significantly affect the expression of $c-M Y C$ in PE/CA-PJ49 tumor cells, but it resulted in a significant reduction of $c-M Y C$ expression in FaDu tumor cells compared to the control $\left(p<0.002,{ }^{* *}\right)$ or to PE/CA-PJ49 tumor cells $(p<0.025, *)$ (Figure 2D, Table 3).

Combined treatment with CisPt $+\mathrm{RSV}$ acted differently on $c-M Y C$ expression in the two tumor cell lines. Therefore, in the case of the PE/CA-PJ49 tumor line, combined treatment with CisPt $+\mathrm{RSV}\left(p<0.02,{ }^{*}\right)$ amplified the effect induced by CisPt, and it resulted in the reduction of $c-M Y C$ expression compared to the effect induced by RSV.

The response of FaDu tumor cells to combined treatment with CisPt $+\mathrm{RSV}$ led to the significant amplification of $c-M Y C$ gene expression, an antagonist effect to the one induced by CisPt $\left(p<0.009,{ }^{* *}\right)$ or RSV $\left(p<0.007,{ }^{* *}\right)$ used separately (Figure 2D; Table 3 ).

\subsection{The Role of RSV in Modulating the Apoptotic Process of Head and Neck Tumor Cells}

In this study, we analyzed the effects induced by RSV on PE/CA-PJ49 and FaDu tumor cells treated with $\mathrm{CisPt}$, in order to reduce the side effects generated by treatment with a cytostatic agent and to increase the efficiency of the cellular response to conventional therapy. Analysis of apoptotic events in PE/CA-PJ49 and FaDu tumor lines, as well as in the HaCaT control cell line, was performed using the Annexin V-FITC Apoptosis Detection Kit I (BD Bioscience Pharmingen, USA), which ensures the double labeling of the cells with annexin V-FITC and propidium iodide (PI). Data were acquired with a BD FACS Canto II flow cytometer using specific acquisition and data analysis programs. Thus, cells positive for annexin $\mathrm{V}$ and negative for PI were considered early apoptotic events (Q4 lower right quadrant), while double-positive cells for annexin V and PI were considered late 
apoptotic events (Q2), and cells positive only for PI were considered necrotic (Q1 upper right quadrant). Cells in Q3 represent living cells.

In order to analyze the effects induced by treatment with CisPt and/or RSV on the apoptotic process in normal human cells, we used the HaCaT cellular line, which we subjected to a treatment regimen similar to the one used in the case of PE/CA-PJ49 and FaDu tumor cell lines (Figures 3 and 4). The results showed that treatment with RSV did not affect $\mathrm{HaCaT}$ control cells, while CisPt induced a significant increase of the apoptotic process $\left(p<0.0001,{ }^{* * *}\right)$ compared to untreated cells. Combined treatment (CisPt $\left.+\mathrm{RSV}\right)$ $\left(p<0.003,{ }^{* *}\right)$ induced apoptosis of HaCaT cells in a much lower percentage than that induced by CisPt. These data suggest the capacity of RSV to protect normal cells from the effect induced by CisPt (Figures 3 and 4 ).

\section{A. HaCaT}

\section{Control}

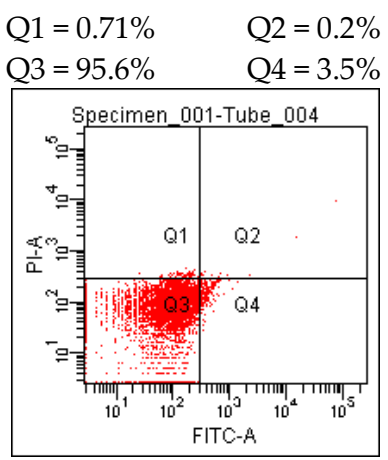

Control

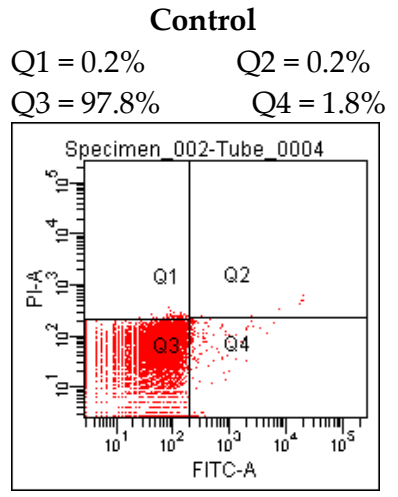

Control

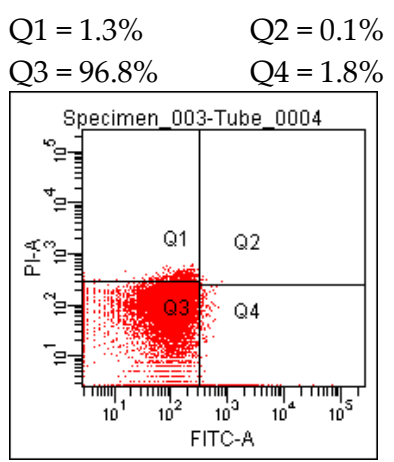

$10 \mu \mathrm{M}$ CisPt
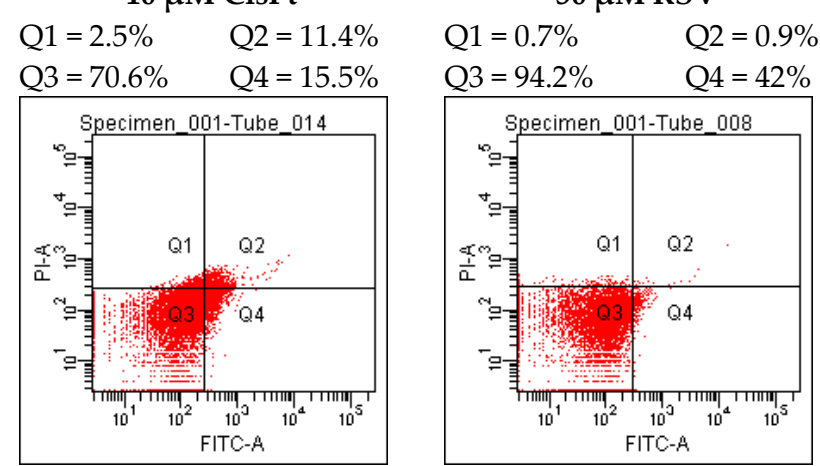

\section{B. PE/CA-PJ49}
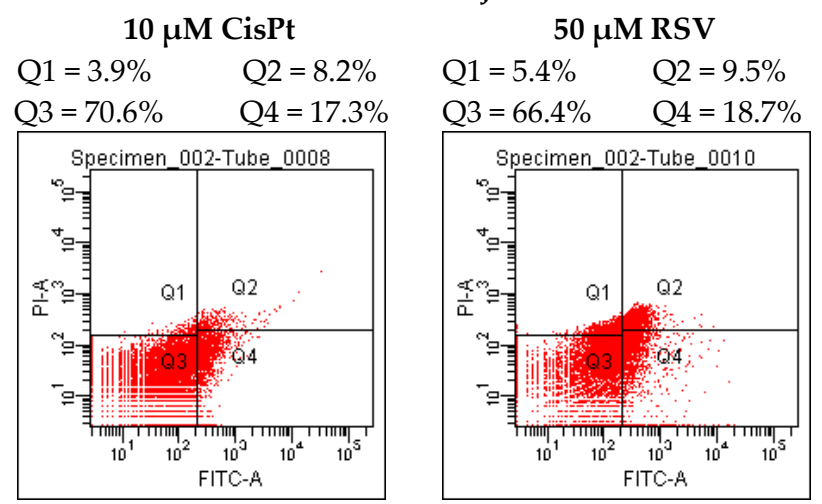

C. $\mathrm{FaDu}$

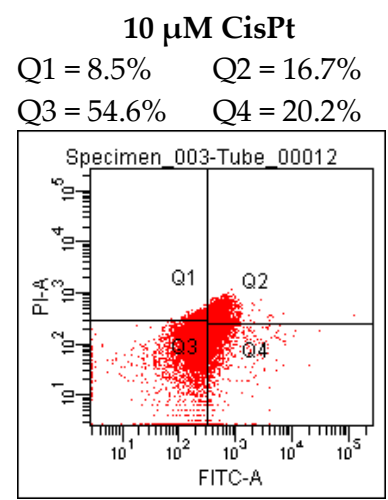

$50 \mu \mathrm{M}$ RSV

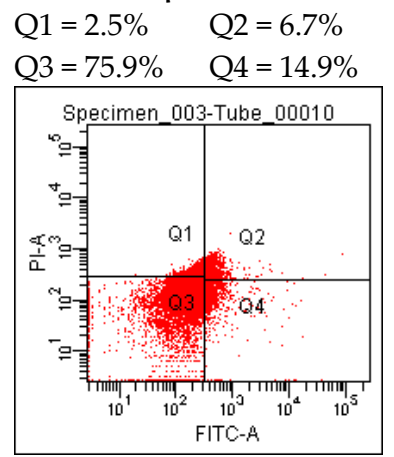

$10 \mu \mathrm{M}$ CisPt+50 $\mu \mathrm{M}$ RSV

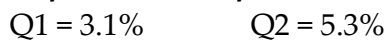

$\mathrm{Q} 3=82.8 \% \quad \mathrm{Q} 4=8.8 \%$

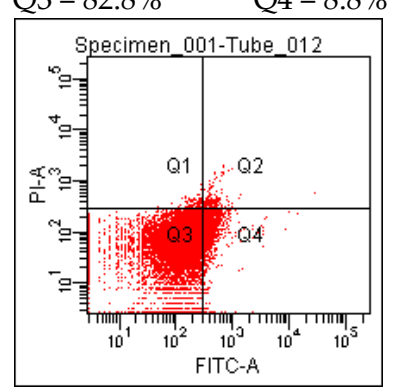

$10 \mu \mathrm{M}$ CisPt+50 $\mu \mathrm{M}$ RSV

$\mathrm{Q} 1=9.4 \% \quad \mathrm{Q} 2=11.2 \%$

$\mathrm{Q} 3=59.5 \% \quad \mathrm{Q} 4=19.9 \%$

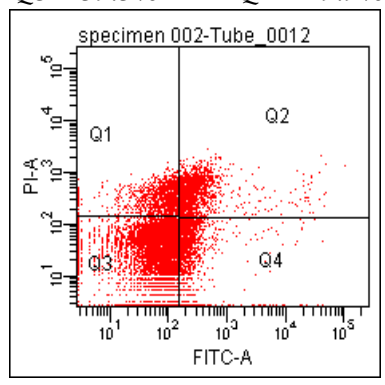

$10 \mu \mathrm{M}$ CisPt+50 $\mu \mathrm{M}$ RSV

$\mathrm{Q} 1=5.5 \% \quad \mathrm{Q} 2=11.7 \%$

$\mathrm{Q} 3=47.9 \% \quad \mathrm{Q} 4=34.9 \%$

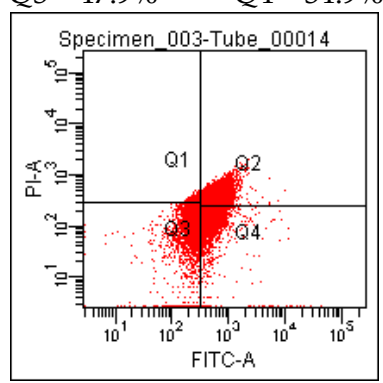

Figure 3. Apoptosis of PE/CA-PJ49 (B) and FaDu (C) tumor cells versus HaCaT (A) normal cells induced by $24 \mathrm{~h}$ treatment with RSV and/or CisPt. 


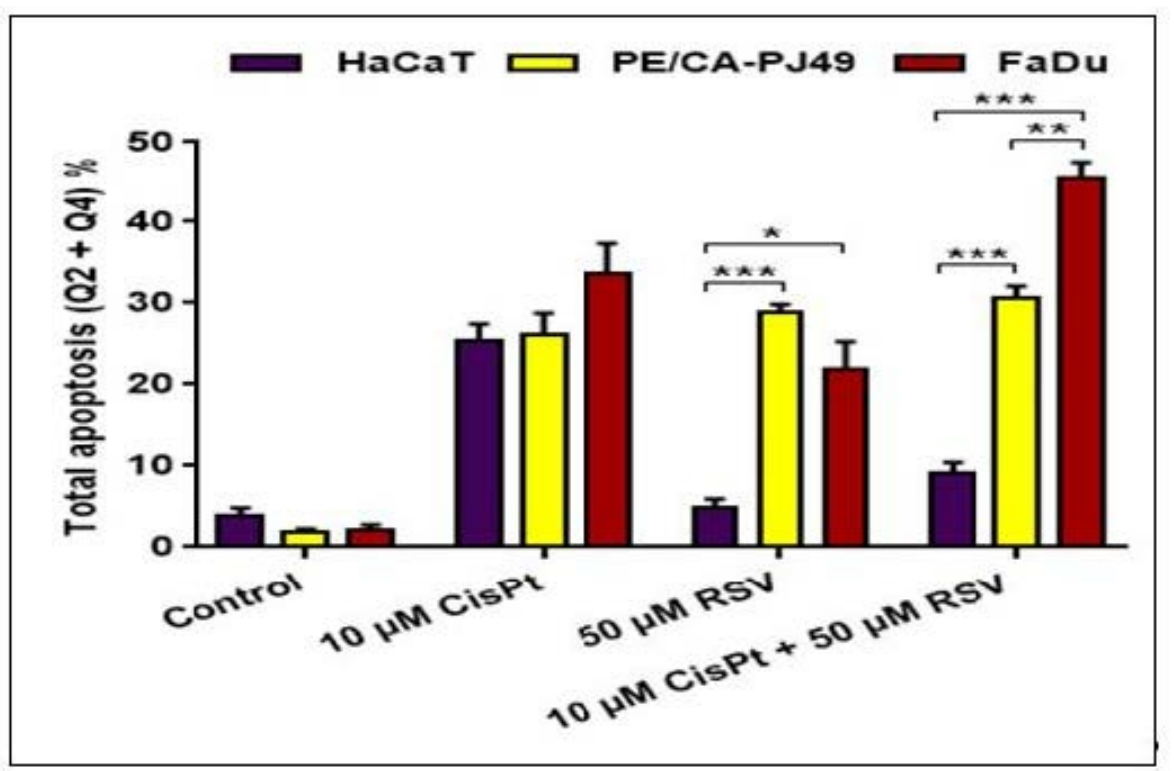

Figure 4. The effect of RSV on the apoptotic process of PE/CA-PJ49 and FaDu tumor cells versus HaCaT normal cells treated $24 \mathrm{~h}$ with CisPt. $\left({ }^{*} p<0.05,{ }^{* *} p<0.005,{ }^{* * *} p<0.0005\right)$.

In PE/CA-PJ49 tumor cells treatment with RSV $\left(p<0.00002,{ }^{* * * *}\right)$ induced apoptosis in a similar manner to $\mathrm{CisPt}\left(p<0.00001,{ }^{* * * *}\right)$ compared to untreated cells (control). Simultaneous treatment with CisPt + RSV on PE/CA-PJ49 tumor cells did not modify the apoptotic process compared to the response to treatment with CisPt $(p<0.1, \mathrm{~ns})$ or RSV $(p<0.4, \mathrm{~ns})$ alone.

In FaDu tumor cells, CisPt $\left(p<0.00001,{ }^{* * * *}\right)$ or RSV $(p<0.0001, * * *)$ applied separately induced a significant increase of the apoptotic process compared to untreated cells (control). Comparative analysis of the effect induced by RSV versus CisPt applied individually showed that RSV activated the apoptotic process of FaDu tumor cells in a slightly different way than $\mathrm{CisPt}\left(p<0.016,{ }^{*}\right)$. When the two agents $\mathrm{CisPt}+\mathrm{RSV}$ were applied simultaneously, a significant increase of the apoptotic process took place compared to the effect induced by CisPt alone $\left(p<0.0007,{ }^{* * *}\right)$ and by RSV alone $\left(p<0.0002,{ }^{* * *}\right)$. Enhanced apoptosis in FaDu cells treated with CisPt + RSV compared to untreated cells $\left(p<0.000002,{ }^{* * * * *)}\right.$ supported the modulatory effect of RSV on apoptosis by potentiating the effect induced by treatment with CisPt alone.

\subsection{The Role of RSV in Modulating the Cell Cycle of Head and Neck Tumor Cells}

Rigorous control of cellular proliferation and the differentiation process is necessary to ensure the normal growth and development of the human body. Any alteration of the cellular division pathways leads to the formation of tumors and the appearance of the carcinogenetic process. Cells from the $\mathrm{HaCaT}$ cell line used as control presented a $20 \%$ distribution of the cells in the synthesis phase (S). Treatment with $10 \mu \mathrm{M}$ CisPt determined an increase of the synthesis phase to $34.3 \%$ in $\mathrm{HaCaT}$ cells compared to $20.1 \%$ registered in untreated cells (Control). These data showed that treatment with CisPt affected the development of the cell cycle in HaCaT normal cells. Treatment of HaCaT cells with $50 \mu \mathrm{M}$ RSV did not seem to significantly affect the distribution of the cellular cycle when applied alone and it did not influence the effect induced by treatment with CisPt when treatment with RSV + CisPt was applied simultaneously (Figures 5 and 6). 


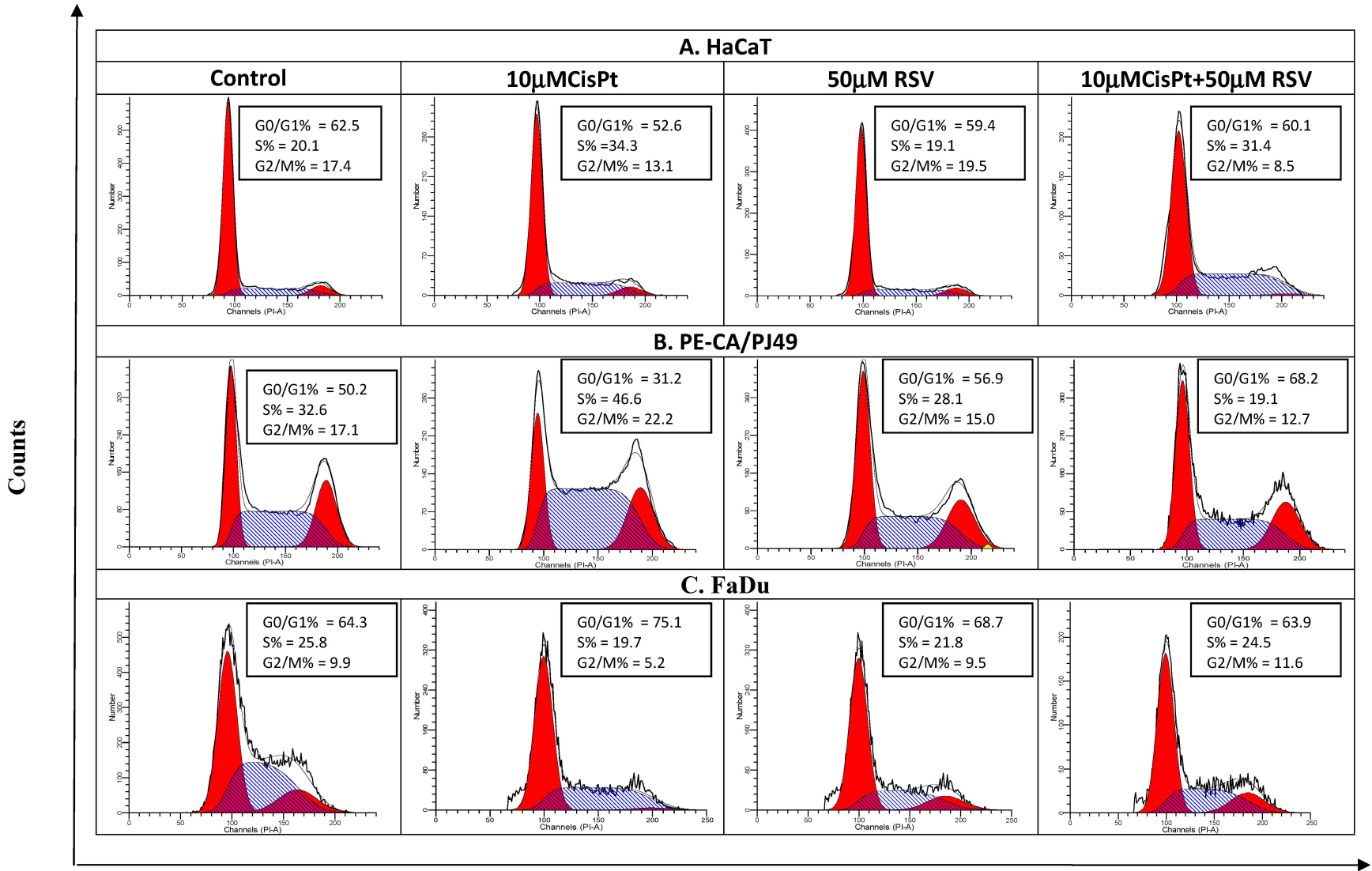

Relative Fluorescence Intensity (PI-A)

Figure 5. The effect of the treatment with CisPt and/or RSV on cell cycle phase distribution in normal cells HaCaT (A), PE/CA-PJ49 (B), and FaDu tumor cells (C) flow cytometry histograms.

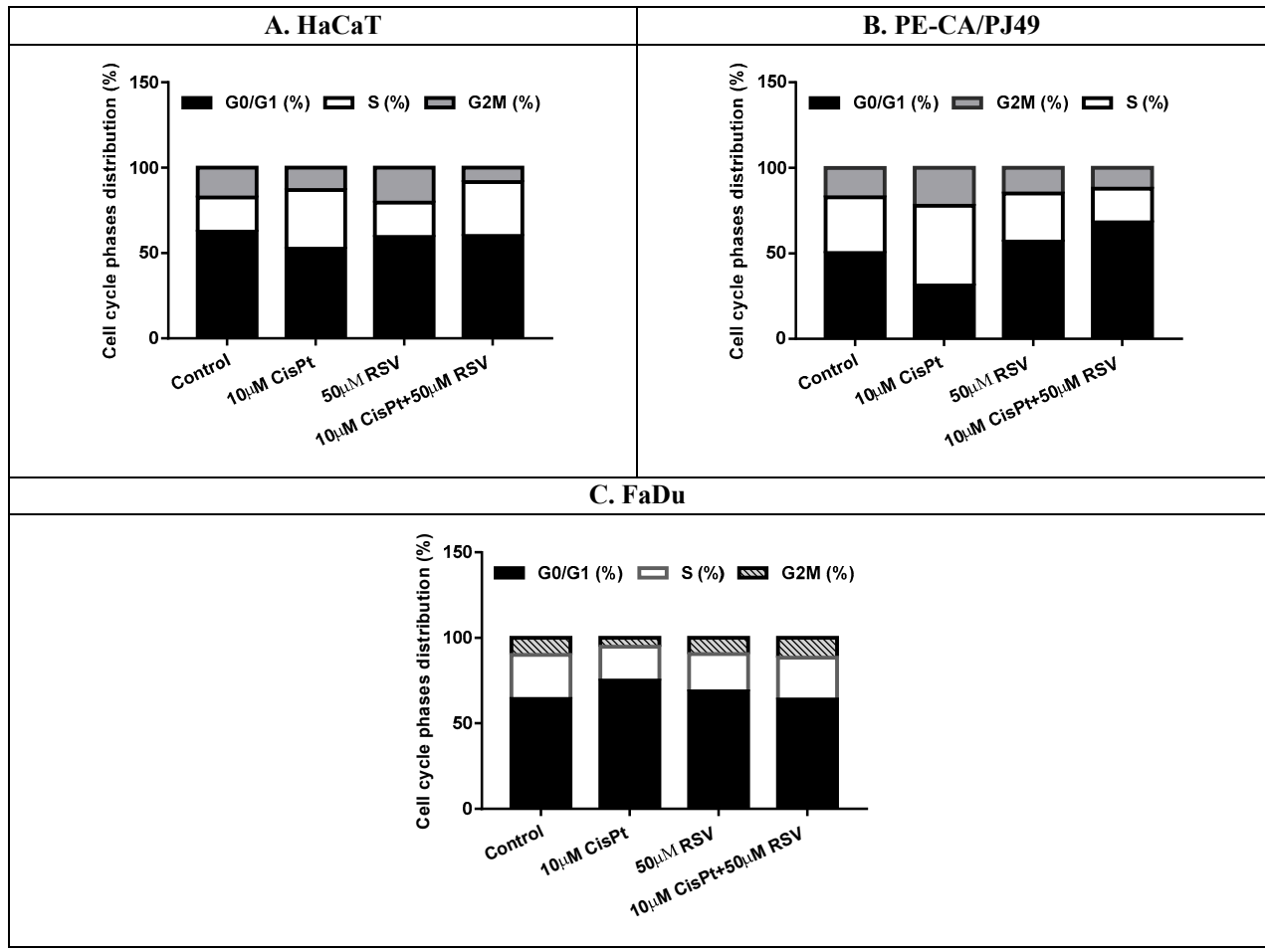

Figure 6. Cell cycle phase distribution (\%) in normal HaCaT cells (A) and tumor cells: PE/CA-PJ49 (B) and $\mathrm{FaDu}(\mathrm{C})$, after treatment with CisPt and/or RSV. 
Analysis of data obtained in the case of PE/CA-PJ49 tumor cells highlighted a different effect than the one found in FaDu tumor cells. Therefore, treatment with $10 \mu \mathrm{M} \mathrm{CisPt}$ in PE/CA-PJ49 tumor cells resulted in a decrease of the G0/G1phase (31.2\% versus control $50.2 \%)$, accompanied by a slight increase of the synthesis phase $(46.6 \%$ versus control $32.6 \%$ ), alongside a lower increase of the G2 + M phase (22.2\% versus control $17.1 \%)$ (Figures 5 and 6). The effects induced by treatment with $50 \mu \mathrm{M}$ RSV on PE/CA-PJ49 showed a slight decrease in the $\%$ of the cells in the synthesis phase (28.1\% versus control $32.6 \%)$ and an increase of the \% of cells in the G0/G1 phase (56.9\% versus control $50.2 \%$ ). The combined treatment CisPt + RSV applied on PE/CA-PJ49 resulted in an increase in the \% of cells in the G0/G1 phase (68.2\% versus control 50.2\%) and a decrease in the proportion of cells in the synthesis phase (19.1\% versus control 32.6\%). The results presented in Figures 5 and 6 show that, although RSV alone acted on the cell cycle in a different manner than CisPt on the PE/CA-PJ49 cells, when RSV + CisPt were used together the dominant effect seemed to be that of RSV, registering a decrease of the \% of cells in the synthesis phase associated with the blocking of the cells in the G0/G1 phase.

Data analysis highlighted the fact that treatment with $10 \mu \mathrm{M} \mathrm{CisPt} \mathrm{in} \mathrm{FaDu} \mathrm{tumor}$ cells caused a decrease of the $\%$ of cells in the synthesis phase (19.7\% versus control $25.8 \%$ ) simultaneously with the growth of the proportion of cells in the G0/G1 phase $(75.1 \%$ versus control $64.3 \%$ ) (Figure 5). Treatment with $50 \mu \mathrm{M}$ RSV seemed to slightly reduce the cells in the synthesis phase in FaDu cells (21.8\% versus control 25.8\%), accompanied by a slight growth of the \% of cells in the G0/G1 phase (68.7\% versus control $64.3 \%)$. Data showed that RSV acted similarly to CisPt and slightly reduced the $\%$ of cells in the synthesis phase (21.8\% versus control 25.8\%). When RSV was applied together with CisPt in FaDu cells we did not record changes in the cell cycle.

\section{Discussion}

The side effects induced by chemotherapeutic agents along with the risk of drug resistance are the obstacles often encountered in the clinic for patients with head and neck malignancies. To reduce the side effects generated by $\mathrm{CisPt}$, we used RSV, a natural product known for its antioxidant and anti-tumor properties.

The data obtained by analyzing the proliferative process induced by RSV and/or CisPt showed that $50 \mu \mathrm{M}$ RSV inhibited the proliferation of $\mathrm{FaDu}$ tumor cells much more than that of PE/CA-PJ49 tumor cells, but the proliferative process was less affected in normal $\mathrm{HaCaT}$ cells. The combined treatment with $10 \mu \mathrm{M}$ CisPt $+50 \mu \mathrm{M}$ RSV influenced the proliferative process in a slightly different manner in the two tumor cell lines. Treatment with $10 \mu \mathrm{M}$ CisPt $+50 \mu \mathrm{M}$ RSV reduced the proliferation of PE/CA-PJ49 tumor cells, but the dominant effect on proliferation was determined by CisPt, while in $\mathrm{FaDu}$ tumor cells RSV amplified the proliferation inhibition induced by CisPt. In addition, when cells were treated simultaneously with $10 \mu \mathrm{M}$ CisPt $+50 \mu \mathrm{M}$ RSV, the RSV had a protective effect against the toxic effect induced by CisPt in normal HaCaT cells.

Unlike normal cells, which, as soon as DNA damage is detected, act immediately to repair it or activate the apoptotic process, in tumor cells these mechanisms of repair or induction of apoptosis are defective and allow excessive cell proliferation. Therefore, we analyzed the effect of RSV on the gene expression process for some genes involved in the apoptotic process or involved in cell cycle blocking in FaDu and PE/CA-PJ49 tumor cells versus normal $\mathrm{HaCaT}$ cells treated or not treated with $\mathrm{CisPt}$.

The first gene expression level analyzed was the TP53, which in normal HaCaT cells treated with RSV or CisPt was slightly low, but when the combined treatment CisPt + RSV was applied an increase (3X) in the TP53 gene expression was recorded, as compared to untreated cells or cells treated separately with CisPt or RSV (Figure 2A). The results showed that in FaDu cells treatment with CisPt and/or RSV acted in the sense of amplifying the expression of the TP53 gene, while in PE/CA-PJ49 tumor cells the combined treatment $\mathrm{CisPt}+\mathrm{RSV}$ led to a decrease of the TP53 gene expression in an antagonist way as compared to the response to CisPt or RSV applied individually (Figure 2A). 
The MDM-2 gene is considered to be a factor involved in the inhibition of the p53 pathway in tumor cells and, therefore, we analyzed how its gene expression is affected by RSV and/or CisPt treatment. MDM-2 gene expression in FaDu cells treated with CisPt and/or RSV appeared to be slightly inhibited. RSV induced in PE/CA-PJ49 cells about 8X amplification of MDM-2 gene expression associated with a slight increase in TP53 expression (1.5X) (Figure 2B). The combined CisPt + RSV treatment appeared to cause an increase (4X) in $M D M-2$ gene expression (Figure 2B) but lower as compared to the RSV-induced effect, and this could be associated with decreased TP53 gene expression (Figure 2A) recorded in CisPt + RSV-treated PE/CA-PJ49 cells.

Comparative analysis of CisPt or the effects induced by RSV applied separately versus CisPt + RSV combination therapy showed that RSV was responsible for modulating MDM2 gene expression in PE/CA-PJ49 tumor cells. The data obtained showed that MDM-2 gene expression in both tumor cell lines was influenced in a different way (Figure 2).

$B C L-2$ is another gene responsible for inhibiting apoptosis and promoting aberrant cell proliferation, so we analyzed how its expression was modulated in tumor cells treated with $\mathrm{RSV}+\mathrm{CisPt}$. Comparative analysis of BCL-2 gene expression in the PE/CA-PJ49 and FaDu cell lines showed that the two types of tumor cells had a similar response to CisPt treatment as well as to the combined CisPt + RSV treatment. RSV treatment applied alone influenced the response of tumor cells in a different way, thus a significant decrease in BCL-2 gene expression in $\mathrm{FaDu}$ was recorded without altering the expression in PE/CA-PJ49 cells. The reduced $B C L-2$ gene expression in FaDu tumor cells could explain the high percentage of apoptosis recorded by RSV alone or RSV + CisPt-treated cells.

Different molecular mechanisms mediate the processes of hyperproliferation and apoptosis, but it seems that the $c-M Y C$ gene has a decisive role in the cell choice between blocking the cell cycle or entering apoptosis. For this reason, we analyzed how treatment with RSV and/or CisPt affected c-MYC expression in tumor cells as compared to normal cells. The modulation of $c-M Y C$ gene expression, when treated with CisPt and/or RSV, was different in the two tumor cell lines. In the FaDu line, both CisPt and RSV administered separately caused a reduction of $c-M Y C$ gene expression, while in the case of combined treatment an amplification of gene expression was registered (2X) (Figure 2D; Table 3). In PE/CA-PJ49 tumor cells treatment with RSV alone acted in an opposite way to the effect induced by CisPt alone on $c-M Y C$ gene expression. When the combination of the two agents was used, RSV amplified the effect induced by CisPt and induced a significant inhibition of $c-M Y C$ expression. In normal HaCaT cells, RSV + CisPt did not significantly affect $c-M Y C$ gene expression. Data obtained showed that RSV can modulate the expression of the analyzed genes in a different way, depending on the morphological, functional, and molecular features of the tumor cell line studied.

Apoptosis is a program that removes damaged cells and thus ensures the regression of tumors after chemotherapy. Tumor suppression is provided by complex networks that include many genes involved in the induction of apoptosis [73]. Therefore, an attempt was made to correlate the level of expression of some genes with the apoptotic process induced by treatment with CisPt and RSV to decipher how tumor cells respond to therapy. Investigations regarding the effects of resveratrol on apoptosis induction in tumor cells $\mathrm{FaDu}$ and PE/CA-PJ49 revealed that RSV can stimulate apoptosis by modulating the expression of some genes (TP53, MDM-2, BCL-2, c-MYC).

The percentage of normal $\mathrm{HaCaT}$ cells entered in apoptosis as a result of treatment with CisPt alone or combined with RSV showed that CisPt affected HaCaT normal cells more than RSV. The high percentage of $\mathrm{HaCaT}$ cells that entered apoptosis after treatment with CisPt + RSV was associated with increased expression of TP53 and MDM-2 genes and a slight increase in the $\mathrm{S}$ phase of the cell cycle. In conclusion, when CisPt $+\mathrm{RSV}$ were used together, RSV seemed to protect $\mathrm{HaCaT}$ normal cells from the effect induced by $\mathrm{CisPt}$ (Figures 3 and 4).

Treatment with CisPt or RSV alone on PE/CA-PJ49 tumor cells caused the cells to enter apoptosis, but in the case of the combined treatment CisPt $+\mathrm{RSV}$, the two agents did 
not have an additive effect on the apoptotic process. In the case of CisPt + RSV combination therapy, an increase in the percentage of cells in apoptosis appeared to be associated with inhibition of $B C L-2$ gene expression. The apoptotic pathway involving the activation of the TP53 gene appeared to be inhibited by the exaggerated increase in $M D M-2$ gene expression (Figure 2B). The important role in inducing apoptosis in PE/CA-PJ49 tumor cells can be attributed to RSV. Data related to the effect of CisPt and/or RSV treatment on the cell cycle showed that cells were blocked in the G0/G1 phase, accompanied by a decrease in phase synthesis associated with decreased $c-M Y C$ gene expression. These correlations showed that when $c-M Y C$ gene expression was diminished by treatment with CisPt and/or RSV (Figure 2D), the apoptotic process was hampered, and we can consider this a weaker response of PE/CA-PJ49 tumor cells to CisPt (Figure 4).

In FaDu tumor cells the apoptotic process induced by treatment with CisPt was more pronounced than in the case of treatment with RSV. When the cells were being treated with CisPt + RSV almost 50\% of FaDu cells entered in apoptosis, suggesting RSV's role in potentiating the effect induced by treatment with CisPt in FaDu cells. The increase in $\mathrm{FaDu}$ cell apoptosis was directly proportional to the increase in expression of the $c-M Y C$ and TP53 genes induced by the combined CisPt + RSV treatment. RSV acted similarly to CisPt, and it slightly reduced the synthesis phase of the FaDu cells but did not affect the cell cycle phases when applied together with CisPt. Thus, the increase of the $c-M Y C$ expression can be associated both with the activation of the apoptotic process and with the increase of the sensitivity to CisPt as a result of its association with RSV.

In conclusion, although the analyzed cellular and molecular processes showed different modes of action of RSV depending on the particularities of the analyzed tumor cells, the results sustained the role of RSV to potentiate the response to CisPt therapy by sensitizing tumor cells to enter into apoptosis or to block the cell cycle. Furthermore, the results showed that RSV can be considered a useful adjuvant in cisplatin therapy because it increases the sensitivity of head and neck tumor cells to cisplatin. Also, the way in which RSV influences tumor cells to enter the apoptotic process or to repair the DNA damages and to continue the cellular cycle depends on the level of gene expression, as well as on the morpho-functional characteristics of the studied tumoral cells.

Data provided by experiments performed on the normal $\mathrm{HaCaT}$ line demonstrated the role of RSV in chemoprevention by modulating cell proliferation or cell cycle and by reducing the effects of CisPt in normal cells.

Finally, on the studied head and neck tumor cells, resveratrol, in addition to its antiproliferative activity, facilitated the induction of apoptosis by CisPt, which could reduce the risk of cell resistance to $\mathrm{CisPt}$ treatment. These promising results will encourage the expansion of the studies on animal models and primary cells obtained from patients with head and neck tumors.

\section{Materials and Methods}

\subsection{Materials}

Resveratrol (RSV) and Cisplatin (CisPt), dimethyl sulfoxide (DMSO), trypsin-EDTA (0.25\% trypsin, 0.03\% EDTA), Glutamine (Glu), Dulbecco's modified Eagle's medium (DMEM), fetal bovine serum (FBS), and 3-(4,5-dimethylthiazol-2-yl)-2,5- diphenyltetrazolium bromide (MTT), phosphate-buffered saline (PBS) pH7.2-7.4; Propidium Iodide (PI) stock solution: $4 \mathrm{mg} / \mathrm{mL}$ PI in PBS; RNase A stock solution: $10 \mathrm{mg} / \mathrm{mL}$ RNase A were purchased from Merck KGaA, Saint Louis, MO, USA.

Annexin V-FITC kit (BD Biosciences, San Jose, CA 95131, USA); High-capacity cDNA Reverse Transcription Kits (Applied Biosystems, Beverly Hills, CA, USA) with the following components: RT-Buffer $10 \times, 1 \mathrm{~mL}$; RT- $10 \times$ random primers, $1 \mathrm{~mL} ; 25 \times \mathrm{dNTP}$ mix (100 mM); MultiScribe ${ }^{\mathrm{TM}}$ Reverse Transcriptase, $50 \mathrm{U} / \mathrm{uL}$; RNaza inhibitor $100 \mathrm{uL}$; Ultrapure water; validated TagMan probes: TP53 (Hs01034249_m1); BCL-2 (Hs00153350_m1); MDM2 (Hs01066930_m1); MYC (Hs00153408_m1); HPRT1 (Hs02800695_m1); qPCR master mix; plates (MicroAmp Fast Optical 96-Well Reaction Plate, $0.1 \mathrm{~mL}$ ). 


\section{Stock Solutions}

Resveratrol and cisplatin were dissolved in dimethyl sulfoxide (DMSO) at a concentration of $50 \mathrm{mM}$ and then a $1 \mathrm{mM}$ stock solution was prepared using Milli-Q water. The stock solutions were filtered using a cellulose acetate hydrophilic filter $(0.20 \mu \mathrm{m})$ (Merck KGaA (Saint Louis, MO, USA), and used to obtain the working concentrations of $10 \mu \mathrm{M}$ for CisPt and $50 \mu \mathrm{M}$ for RSV by performing dilutions in the culture medium.

\subsection{Experimental Methods}

\subsubsection{Cell Lines Culture}

The squamous tongue carcinoma cell line PE/CA-PJ49 was from the European Collection of Authenticated Cell Cultures (ECACC cat. no. 0060606, Culture Collections Public Health England, Porton Down, Salisbury, SP4 0JG, UK), the squamous pharyngeal carcinoma cell line FaDu was obtained from the American Type Culture Collection (Cat. no ATCC-HTB-43, ATCC Manassas, VA, USA), HaCaT cells, immortalized human keratinocyte line, were provided by Cell Line Service GmbH (Cat no.330493, Eppelheim, Germany) and were grown and maintained in Dulbecco's modified Eagle's medium (DMEM) supplemented with $10 \%$ fetal bovine serum (FBS), $2 \mathrm{mM}$ glutamine and then maintained at $37^{\circ} \mathrm{C}$ in a $5 \% \mathrm{CO}_{2}$ humidified incubator. The cell lines showing adherent epithelial type morphology and the subconfluent cultures (70-80\%) were split 1:4-1:8 (i.e., seeding at $1-3 \times 10,000$ cells $\left./ \mathrm{cm}^{2}\right)$ using trypsin-EDTA ( $0.25 \%$ trypsin, $0.03 \%$ EDTA). The adherent cells were incubated for 24,48 , or $72 \mathrm{~h}$ either in the presence of the drugs (CisPt and / or RSV) or in vehicle control (DMSO $\leq 0.1 \%$ ). The treated and untreated cells were used to analyze the proliferative process, gene expression levels, apoptosis, distribution of cell cycle phases, or for PCR assays. In all experiments described in this study, all untreated cells were designated as control cells [74].

\subsubsection{Cellular Proliferation Assay}

Previous to the proliferation test, in order to select the optimal working concentrations, the tumor and normal cells were treated for 24,48 , and $72 \mathrm{~h}$ with RSV or CisPt in concentrations ranging from 2 to $256 \mu \mathrm{M}$. Cell viability was measured with the 3-(4,5dimethylthiazol-2-yl)-2,5-diphenyltetrazolium bromide (MTT) colorimetric assay (Merck $\mathrm{KGaA}$, Saint Louis, MO, USA). Subsequently, the cells were incubated for $4 \mathrm{~h}$ with $20 \mu \mathrm{L}$ $5 \mathrm{mg} / \mathrm{mL}$ MTT solution at $37^{\circ} \mathrm{C}$. The MTT liquid was aspirated and $100 \mu \mathrm{L}$ DMSO was added to each well and the plate was shaken for $10 \mathrm{~min}$. The absorbance of each well was determined at a wavelength of $570 \mathrm{~nm}$ using a Dynex plate reader (Dynex Technologies, Chantilly, VA, USA). The drug response curve was generated, and IC50 (the concentration required to kill $50 \%$ of the cell population) was calculated using GraphPad Prism version 7.00. For the proliferation assay, PE/CA-PJ49, FaDu, and HaCaT cells $\left(5 \times 10^{3}\right.$ cells/well) were seeded in a 96-well culture plate and then treated with $50 \mu \mathrm{M}$ $\mathrm{RSV}$ and/or $10 \mu \mathrm{M}$ CisPt and incubated at $37{ }^{\circ} \mathrm{C}$ with $5 \% \mathrm{CO}_{2}$ for 24,48 or $72 \mathrm{~h}$. The cell proliferation performed using the CellTiter $96^{\circledR}$ AQueous One Solution Cell Proliferation Assay (Promega, Saint Louis, MO, USA) was based on the reduction of yellow MTS tetrazolium salt by the viable cells and generation of colored formazan soluble in the culture medium. The product was spectrophotometrically quantified by measuring the absorbance at $\lambda=490 \mathrm{~nm}$ using a Dynex plate reader (Dynex Technologies, MRS, USA). Results were expressed as mean values of three determinations \pm standard deviation (SD). Untreated cells served as control and were considered to have a proliferation index (IP) equal to 1. Index proliferation (IP) was calculated using the optical density (OD) as follows: $\mathrm{IP}=($ ODtreatment - ODblank $) /($ ODcontrol - ODblank $)[75]$.

\subsubsection{Real-Time PCR for Analysis of Gene Expression}

A number of $5 \times 10^{6}$ cells treated with $50 \mu \mathrm{M}$ RSV and/or $10 \mu \mathrm{M}$ CisPt for $24 \mathrm{~h}$ were used to extract total RNA with Trizol Reagent (Invitrogen, Carlsbad, CA, USA) as indicated in the protocol. The concentration of isolated RNA was assessed using a 
NanoDrop spectrophotometer (NanoDropTechnologies, Montchanin, DE, USA). RNA purity was determined by A260/A280 ratios (an A260/A230 ratio as close as possible to 2 indicates the presence of highly purified RNA). For each sample, $2 \mu \mathrm{g}$ of total RNA was reverse-transcripted using the High-capacity cDNA Reverse Transcription Kit from Applied Biosystems, Beverly Hills, CA, USA, using non-specific, random primers, following the manufacturer's instructions. The obtained cDNA was stored at $4{ }^{\circ} \mathrm{C}$ and 50 ng of cDNA from each sample was used in the amplification reaction real-time PCR (RT-PCR).

The analysis of the gene expression level (TP53, MDM-2, BCL-2, MYC) was performed by real-time PCR using a ViiA ${ }^{\mathrm{TM}} 7$ Real-Time PCR System by setting the ABI 7500 Fast program (Applied Biosystems, Beverly Hills, CA, USA). The reference gene used in the experiments was HPRT1 (hypoxanthine ribosyltransferase 1) because this gene is found in all cell types and has a stable, relatively constant expression regardless of experimental conditions. The reference gene is useful in calibrating and interpreting RT-PCR [76,77]. Each sample was performed in duplicate. Thermal cycling conditions of PCR were as follows: $95^{\circ} \mathrm{C}$ for $10 \mathrm{~min}$ for amplification activation and 40 cycles at $95^{\circ} \mathrm{C}$ for $12 \mathrm{~s}$ and $60^{\circ} \mathrm{C}$ for $15 \mathrm{~s}$. The amplification was examined with the use of the 7300 Real-Time PCR System-SDS, Version 1.4, program. Results were analyzed with Relative Quantitation RQ study software (Applied Biosystems) applying the Delta-Delta-Ct $(\Delta \Delta \mathrm{Ct})$ Algorithm an approximation method to determine relative gene expression with RT-PCR experiments, in order to collect, analyse and visualize RT-PCR results. The $2-\Delta \Delta \mathrm{Ct}$ value obtained indicates how many times the expression of the gene has increased or decreased compared to the control sample (untreated cells).

\subsubsection{Flow Cytometry Methods}

- Apoptosis Analysis The apoptosis assay was carried out with the Annexin V-FITC Apoptosis Detection Kit (BD Biosciences, San Jose, CA 95131, USA) according to manufacturer protocol. The cells were cultured for $24 \mathrm{~h}$ and treated with $10 \mu \mathrm{M}$ CisPt and/or $50 \mu \mathrm{M}$ RSV for another $24 \mathrm{~h}$. Then, treated and untreated cells were detached using trypsin-EDTA $(0.25 \%)$ solution, centrifugated $10 \mathrm{~min}$ at $200 \times \mathrm{g}$, and were resuspended in cold binding buffer and staining simultaneously with $5 \mu \mathrm{L}$ FITCAnnexin V (green fluorescence) and $5 \mu \mathrm{L}$ propidium iodide (PI) in the dark, at room temperature for $15 \mathrm{~min}$. A total of $400 \mu \mathrm{L}$ of Annexin V binding buffer was added and 10,000 cells/sample were acquired using a BD Canto II flow cytometer. The analysis was done using DIVA 6.2 software to discriminate viable cells $\left(\mathrm{FITC}^{-} \mathrm{PI}^{-}\right)$ from necrotic cells $\left(\mathrm{FITC}^{+} \mathrm{PI}^{+}\right)$and early apoptosis $\left(\mathrm{FITC}^{+} \mathrm{PI}^{-}\right)$from late apoptosis [78].

- Cell Cycle Analysis by Flow Cytometry For analysis of cell cycle distribution, the treated and untreated cells were harvested, washed in a cold PBS solution, and fixed with $70 \%$ ethanol for at least $24 \mathrm{~h}$ at $4{ }^{\circ} \mathrm{C}$. After $24 \mathrm{~h}$, the cells were stained with propidium iodide (PI), an agent that intercalates into the major groove of doublestranded DNA and produces a highly fluorescent adduct that can be excited at $488 \mathrm{~nm}$ with a broad emission around $600 \mathrm{~nm}$. Since PI can also bind to double-stranded RNA, it is necessary to treat the cells with RNase for optimal DNA resolution. Cells $\left(1 \times 10^{6}\right.$ cells $\left./ \mathrm{mL}\right)$ were washed in PBS and centrifuged at $300 \times g, 5 \mathrm{~min}$ at $4{ }^{\circ} \mathrm{C}$. The pellet of the cells was incubated for $10 \mathrm{~min}$ at $37^{\circ} \mathrm{C}$ with $0.5 \mathrm{mg} / \mathrm{sample}$ RNase A and then $10 \mu \mathrm{g} /$ sample of PI staining solution was added to cell pellet, mixed well, and incubated $10 \mathrm{~min}$ at $37^{\circ} \mathrm{C}$. The samples were stored at $4{ }^{\circ} \mathrm{C}$ until analyzed by flow cytometry. A minimum of 20,000 events for each sample was collected using a FACS CantoII flow cytometer and ModFIT software (BD Biosciences, San Jose, CA 95131, USA) and used to determine the cell cycle phase distribution after debris exclusion [79].

- Statistical Analysis All data analyses were performed using GraphPad Prism 7 (GraphPad Software Inc., La Jolla, CA, USA). The differences between the treatment and control groups or between different treatments were statistically analyzed using un- 
paired two-tailed t-test and one-way ANOVA. Statistical significance was considered at $p<0.05$.

Author Contributions: M.B. and V.R., created the outline and drafted the manuscript, designed the research, data acquisition, analysis, and interpretation of data. M.M., R.H., G.G.P.-M., and C.D.S. performed the experiments, data acquisition, analysis, and interpretation of data and manuscript drafting. N.R., C.C.D. contributed to statistical analysis, critical revision of the manuscript for important intellectual content. All authors have read and agreed to the published version of the manuscript.

Funding: This research was funded by Competitiveness Operational Programme (COP) A1.1.4. Grant ID: P_37_798 MyeloAL-EDiaProT, Contract 149/26.10.2016, (SMIS: 106774) and PN-III-P2-2.1PED-2019, Contract nr. 383PED/2020 “Development of anticancer nanoparticulate systems based on novel metal complexes" (FLAVONAN) and ERAPerMed_Joint Transnational Call for Proposal (2019) for Personalised Medicine: Multidisciplinary Research towards Implementation, BronchoBOC, Contract 140/2020.

Conflicts of Interest: The authors declare no conflict of interest.

\section{References}

1. Siegel, R.L.; Miller, K.D.; Jemal, A. Cancer statistics. CA Cancer J. Clin. 2016, 66, 7-30. [CrossRef]

2. Ndagi, U.; Mhlongo, N.; Soliman, M.E. Metal complexes in cancer therapy-an update from drug design perspective. Drug Des. Dev. Ther. 2017, 11, 599-616. [CrossRef]

3. Todd, R.C.; Lippard, S.J. Structure of duplex DNA containing the cisplatin 1, 2-\{Pt (NH3) 2\} 2+-d (GpG) cross-link at $1.77 \AA$ resolution. J. Inorg. Biochem. 2010, 104, 902-908. [CrossRef]

4. Reedijk, J. Platinum anticancer coordination compounds: Study of DNA binding inspires new drug design. Eur. J. Inorg. Chem. 2009, 10, 1303-1312. [CrossRef]

5. Galluzzi, L.; Senovilla, L.; Vitale, I.; Michels, J.; Martins, I.; Kepp, O.; Castedo, M.; Kroemer, G. Molecular mechanisms of cisplatin resistance. Oncogene 2012, 31, 1869-1883. [CrossRef]

6. Eckstein, N. Platinum resistance in breast and ovarian cancer cell lines. J. Exp. Clin. Cancer Res. 2011, 30, 91. [CrossRef] [PubMed]

7. Damia, G.; Broggini, M. Platinum resistance in ovarian cancer: Role of DNA repair. Cancers 2019, 11, 119. [CrossRef] [PubMed]

8. Amable, L. Cisplatin resistance and opportunities for precision medicine. Pharmacol. Res. 2016, 106, 27-36. [CrossRef] [PubMed]

9. Rocha, C.R.R.; Silva, M.M.; Quinet, A.; Cabral-Neto, J.B.; Menck, C.F.M. DNA repair pathways and cisplatin resistance: An intimate relationship. Clinics 2018, 73, 478. [CrossRef]

10. Yang, T.; Chen, M.; Chen, T.; Thakur, A. Expression of the copper transporters hCtr1; ATP7A and ATP7B is associated with the response to chemotherapy and survival time in patients with resected non-small cell lung cancer. Oncol. Lett. 2015, 10, 2584-2590. [CrossRef]

11. Öhrvik, H.; Logeman, B.; Turk, B.; Reinheckel, T.; Thiele, D.J. Cathepsin protease controls copper and cisplatin accumulation via cleavage of the Ctr1 metal-binding ectodomain. J. Biol. Chem. 2016, 291, 13905-13916. [CrossRef]

12. Galluzzi, L.; Vitale, I.; Michels, J.; Brenner, C.; Szabadkai, G.; Harel-Bellan, A.; Castedo, M.; Kroemer, G.J.C.D. Systems biology of cisplatin resistance: Past, present and future. Cell Death Dis. 2014, 5, 1257. [CrossRef]

13. Chen, S.-H.; Chang, J.-Y. New Insights into Mechanisms of Cisplatin Resistance: From Tumor Cell to Microenvironment. Int. J. Mol. Sci. 2019, 20, 4136. [CrossRef]

14. Cocetta, V.; Ragazzi, E.; Montopoli, M. Mitochondrial Involvement in Cisplatin Resistance. Int. J. Mol. Sci. 2019, 20, 3384. [CrossRef]

15. Kjaer, T.N.; Ornstrup, M.J.; Poulsen, M.M.; Jorgensen, J.O.; Hougaard, D.M.; Cohen, A.S.; Neghabat, S.; Richelsen, B.; Pedersen, S.B. Resveratrol reduces the levels of circulating androgen precursors but has no effect on, testosterone, dihydrotestosterone, PSA levels or prostate volume. A 4-month randomised trial in middle-aged men. Prostate 2015, 75, 1255-1263. [CrossRef] [PubMed]

16. Howard, J.D.; Lu, B.; Chung, C.H. Therapeutic targets in head and neck squamous cell carcinoma: Identification, evaluation, and clinical translation. Oral Oncol. 2012, 48, 10-17. [CrossRef] [PubMed]

17. Patel, K.R.; Scott, E.; Brown, V.A.; Gescher, A.J.; Steward, W.P.; Brown, K. Clinical trials of resveratrol. Ann. N. Y. Acad. Sci. 2011, 1215, 161-169. [CrossRef] [PubMed]

18. Cottart, C.H.; Nivet-Antoine, V.; Laguillier-Morizot, C.; Beaudeux, J.L. Resveratrol bioavailability and toxicity in humans. Mol. Nutr. Food Res. 2010, 54, 7-16. [CrossRef] [PubMed]

19. Ioan, D.C.; Rău, I.; Albu Kaya, M.G.; Radu, N.; Bostan, M.; Zgârian, R.G.; Tihan, G.T.; Dinu-Pîrvu, C.E.; Lupuliasa, A.; Ghica, M.V. Ciprofloxacin-Collagen-Based Materials with Potential Oral Surgical Applications. Polymers 2020, 12, 1915. [CrossRef] [PubMed]

20. Ng, C.; Yen, H.; Hsiao, H.-Y.; Su, S.-C. Phytochemicals in skin cancer prevention and treatment: An updated review. Int. J. Mol. Sci. 2018, 19, 941. [CrossRef] [PubMed]

21. Pangeni, R.; Sahni, J.K.; Ali, J.; Sharma, S.; Baboota, S. Resveratrol: Review on therapeutic potential and recent advances in drug delivery. Expert Opin. Drug Deliv. 2014, 11, 1285-1298. [CrossRef] 
22. Kim, S.-M.; Kim, S.Z. Biological Activities of Resveratrol against Cancer. J. Phys. Chem. Biophys. 2018, 7, 267. [CrossRef]

23. Gescher, A.; Steward, W.P.; Brown, K. Resveratrol in the management of human cancer: How strong is the clinical evidence? Ann. N. Y. Acad. Sci. 2013, 1290, 12-20. [CrossRef] [PubMed]

24. Patel, K.R.; Brown, V.A.; Jones, D.J.; Britton, R.G.; Hemingway, D.; Miller, A.S.; West, K.P.; Booth, T.D.; Perloff, M.; Crowell, J.A. Clinical pharmacology of resveratrol and its metabolites in colorectal cancer patients. Cancer Res. 2010, 70, 7392-7399. [CrossRef] [PubMed]

25. Mihaila, M.; Bostan, M.; Hotnog, D.; Ferdes, M.; Brasoveanu, L.I. Real-time analysis of quercetin, resveratrol and /or doxorubicin effects in MCF-7 cells. Rom. Biotechnol. Lett. 2013, 18, 8106-8114.

26. Ko, J.H.; Sethi, G.; Um, J.Y.; Shanmugam, M.K.; Arfuso, F.; Kumar, A.P.; Bishayee, A.; Ahn, K.S. The Role of Resveratrol in Cancer Therapy. Int. J. Mol. Sci. 2017, 18, 2589. [CrossRef] [PubMed]

27. Jiang, Z.; Chen, K.; Cheng, L.; Yang, W. Resveratrol and cancer treatment: Updates. Ann. N. Y. Acad. Sci. 2017, 1403, 59-69. [CrossRef] [PubMed]

28. Bostan, M.; Petrica-Matei, G.G.; Hainarosie, R.; Radu, N.; Roman, V. Apoptosis and Autophagy Pathways, A New Therapy Approach in Head and Neck Cancer; SM Group Open Access eBooks-Head and Neck Cancer: Dover, DE, USA, 2017; pp. 1-9.

29. Shrotriya, S.; Agarwal, R.; Sclafani, R.A. A perspective on chemoprevention by resveratrol in head and neck squamous cell carcinoma. Adv. Exp. Med. Biol. 2015, 815, 333-348. [PubMed]

30. Bostan, M.; Petrica-Matei, G.G.; Radu, N.; Hainarosie, R.; Stefanescu, C.D.; Diaconu, C.C.; Roman, V. The Effect of Resveratrol or Curcumin on Head and Neck Cancer Cells Sensitivity to the Cytotoxic Effects of Cisplatin. Nutrients 2020, 12, 2596. [CrossRef]

31. Fang, Y.; DeMarco, V.G.; Nicholl, M.B. Resveratrol enhances radiation sensitivity in prostate cancer by inhibiting cell proliferation and promoting cell senescence and apoptosis. Cancer Sci. 2012, 103, 1090-1098. [CrossRef]

32. Lee, T.Y.; Tseng, Y.H. The Potential of Phytochemicals in Oral Cancer Prevention and Therapy: A Review of the Evidence. Biomolecules 2020, 10, 1150. [CrossRef] [PubMed]

33. Gupta, S.C.; Kannappan, R.; Reuter, S.; Kim, J.H.; Aggarwal, B.B. Chemosensitization of tumors by resveratrol. Ann. N. Y. Acad. Sci. 2011, 1215, 150-160. [CrossRef]

34. Vang, O.; Ahmad, N.; Baile, C.A.; Baur, J.A.; Brown, K.; Csiszar, A.; Das, D.K.; Delmas, D.; Gottfried, C.; Lin, H.Y. What is new for an old molecule? Systematic review and recommendations on the use of resveratrol. PLoS ONE. 2011, 6, e19881. [CrossRef]

35. Nunes, T.; Almeida, L.; Rocha, J.-F.; Falcão, A.; Fernandes-Lopes, C.; Loureiro, A.I.; Wright, L.; Vaz-da-Silva, M.; Soares-da-Silva, P. Pharmacokinetics of trans-resveratrol following repeated administration in healthy elderly and young subjects. J. Clin. Pharmacol. 2009, 49, 1477-1482. [CrossRef] [PubMed]

36. Smoliga, J.M.; Vang, O.; Baur, J.A. Challenges of translating basic research into therapeutics: Resveratrol asan example. J. Gerontol. Ser. A Biol. Sci. Med. Sci. 2012, 67, 158-167. [CrossRef] [PubMed]

37. Gatz, S.A.; Wiesmuller, L. Take a break-resveratrol in action on DNA. Carcinogenesis 2009, 29, 321-332. [CrossRef] [PubMed]

38. Liu, B.; Zhou, Z.; Zhou, W.; Liu, J.; Zhang, Q.; Xia, J.; Liu, J.; Chen, N.; Li, M.; Zhu, R. Resveratrol inhibits proliferation in human colorectal carcinoma cells by inducing G1/S phase cell cycle arrest and apoptosis through caspase/cyclin CDK pathways. Mol. Med. Rep. 2014, 10, 1697-1702. [CrossRef] [PubMed]

39. Meeran, S.M.; Katiyar, S.K. Cell cycle control as a basis for cancer chemoprevention through dietary agents. Front. Biosci. 2008, 13, 2191-2202. [CrossRef]

40. Joe, A.K.; Liu, H.; Suzui, M.; Vural, M.E.; Xiao, D.; Weinstein, I.B. Resveratrol induces growth inhibition, S-phase arrest, apoptosis, and changes in biomarker expression in several human cancer cell lines. Clin. Cancer Res. 2002, 8, 893-903.

41. Casanova, F.; Quarti, J.; da Costa, D.C.; Ramos, C.A.; da Silva, J.L.; Fialho, E. Resveratrol chemosensitizes breast cancer cells to melphalan by cell cycle arrest. J. Cell. Biochem. 2012, 113, 2586-2596. [CrossRef]

42. Aguilar, R.M.; Marchat, L.A.; Ocampo, E.A.; Gariglio, P.; Mena, J.G.; Sepúlveda, N.V.; Castillo, M.M.; Camarillo, C.L. Resveratrol inhibits cell cycle progression by targeting Aurora kinase A and Polo-like kinase 1 in breast cancer cells. Oncol. Rep. 2016, 35, 3696-3704. [CrossRef]

43. Cummings, J.; Ward, T.H.; Ranson, M.; Dive, C. Apoptosis pathway-targeted drugs-From the bench to the clinic. Biochim. Biophys. Acta 2004, 1705, 53-66. [CrossRef]

44. Bostan, M.; Mihaila, M.; Hotnog, C.; Bleotu, C.; Anton, G.; Roman, V.; Brasoveanu, L.I. Chapter Modulation of Apoptosis in Colon Cancer Cells by Bioactive Compounds. In Colorectal Cancer-From Pathogenesis to Treatment; Rodrigo, L., Ed.; Intech: Rijeka, Croatia, 2016.

45. Delbridge, A.R.D.; Valente, L.J.; Strasser, A. The Role of the Apoptotic Machinery in Tumor Suppression. Cold Spring Harb. Perspect. Biol. 2012, 4, 8789. [CrossRef]

46. Neagu, M.; Constantin, C.; Bostan, M.; Caruntu, C.; Ignat, S.R.; Dinescu, S.; Costache, M. Proteomics technologies “lens” for epithelial-mesenchymal transition process identification in oncology. Anal. Cell. Pathol. 2019, 2019, 17. [CrossRef] [PubMed]

47. Neergheen, V.S.; Bahorun, T.; Taylor, E.W.; Jen, L.S.; Aruoma, O.I. Targeting specific cell signaling transduction pathways by dietary and medicinal phytochemicals in cancer chemoprevention. Toxicology 2010, 278, 229-241. [CrossRef] [PubMed]

48. Hsieh, T.C.; Wong, C.; Bennett, J.D.; Wu, J.M. Regulation of p53 and cell proliferation by resveratrol and its derivatives in breast cancer cells: An in silico and biochemical approach targeting integrin $\alpha \mathrm{v} \beta 3$. Int. J. Cancer. 2011, 129, 2732-2743. [CrossRef] [PubMed] 
49. Perrone, F.; Bossi, P.; Cortelazzi, B. TP53 mutations and pathologic complete response to neoadjuvant cisplatin and fluorouracil chemotherapy in resected oral cavity squamous cell carcinoma. J. Clin. Oncol. 2010, 28, 761-766. [CrossRef]

50. Wang, Z.; Li, B. Mdm2 links genotoxic stress and metabolism to p53. Protein Cell 2010, 1, 1063-1072. [CrossRef]

51. Millon, R.; Muller, D.; Schultz, I. Loss of MDM2 expression in human head and neck squamous cell carcinomas and clinical significance. Oral Oncol. 2001, 37, 620-631. [CrossRef]

52. Miliani de Marval, P.L.; Zhang, Y. The RP-Mdm2-p53 pathway and tumorigenesis. Oncotarget 2011, 2, 234-238. [CrossRef]

53. Furgason, J.M.; Bahassi, M. Targeting DNA repair mechanisms in cancer. Pharmacol. Ther. 2012, 137, 298-308. [CrossRef] [PubMed]

54. Biliran, H.; Banerjee, S.; Thakur, A.; Sarkar, F.H.; Bollig, A.; Ahmed, F.; Wu, J.; Sun, Y.; Liao, J.D. c-Myc-induced chemosensitization is mediated by suppression of cyclin D1 expression and nuclear factor-kappa B activity in pancreatic cancer cells. Clin. Cancer Res. 2007, 13, 2811-2821. [CrossRef] [PubMed]

55. Lin, C.Y.; Lovén, J.; Rahl, P.B.; Paranal, R.M.; Burge, C.B.; Bradner, J.E.; Lee, T.I.; Young, R.A. Transcriptional amplification in tumor cells with elevated c-Myc. Cell 2012, 151, 56-67. [CrossRef] [PubMed]

56. Dowsett, M.; González-Angulo, A.M.; Mills, G.B.; Miller, W.R.; Wu, H. A gene expression signature from human breast cancer cells with acquired hormone independence identifies MYC as a mediator of antiestrogen resistance. Clin. Cancer Res. 2011, 17, 2024-2034.

57. Boone, D.N.; Qi, Y.; Li, Z.; Hann, S.R. Egr1 mediates p53-independent c-Myc-induced apoptosis via a noncanonical ARFdependent transcriptional mechanism. Proc. Natl. Acad. Sci. USA 2011, 108, 632-637. [CrossRef]

58. Nie, Z.; Hu, G.; Wei, G.; Cui, K.; Yamane, A.; Resch, W.; Wang, R.; Green, D.R.; Tessarollo, L.; Casellas, R. c-Myc is a universal amplifier of expressed genes in lymphocytes and embryonic stem cells. Cell 2012, 151, 68-79. [CrossRef]

59. Dang, C.V.; Le, A.; Gao, P. MYC-induced cancer cell energy metabolism and therapeutic occasions. Clin. Cancer Res. 2009, 15, 6479-6483. [CrossRef]

60. Ozdek, A.; Sarac, S.; Akyol, M.U.; Sungur, A.; Yilmaz, T. c-myc and bcl-2 expression in supraglottic squamous cell carcinoma of the larynx. Otolaryngol. Head Neck Surg. 2004, 131, 77-83. [CrossRef]

61. Zerp, S.F.; Stoter, T.R.; Hoebers, F.J.P.; Van den Brekel, M.W.M.; Dubbelman, R.; Kuipers, G.K.; Lafleur, M.V.M.; Slotman, B.J.; Verheij, M. Targeting anti-apoptotic Bcl-2 by AT-101 to increase radiation efficacy: Data from in vitro and clinical pharmacokinetic studies in head and neck cancer. Radiat. Oncol. 2015, 10, 158. [CrossRef]

62. Li, Y.; Cui, J.T. Inhibition of Bcl-2 potentiates AZD-2014-induced anti-head and neck squamous cell carcinoma cell activity. Biochem. Biophys. Res. Commun. 2016, 477, 607-613. [CrossRef]

63. Opferman, J.T. Attacking cancer's Achilles heel: Antagonism of anti-apoptotic BCL-2 family members. FEBS J. 2016, 283, 2661-2675. [CrossRef]

64. Bostan, M.; Radu, N.; Babeanu, N.; Zaharie, M.G.; Horatiu Tanasescu, C.A. Biological properties of a biomaterial obtained from Syzygiumaromaticum. Mol. Cryst. Liq. Cryst. 2019, 695, 45-52. [CrossRef]

65. Stecoza, C.E.; Nitulescu, G.M.; Draghici, C.; Caproiu, M.T.; Olaru, O.T.; Bostan, M.; Mihaila, M. Synthesis and Anticancer Evaluation of New 1,3,4-Oxadiazole Derivatives. Pharmaceuticals 2021, 14, 438. [CrossRef]

66. Machana, S.; Weerapreeyakul, N.; Barusrux, S.; Nonpunya, A.; Sripanidkulchai, B.; Thitimetharoch, T. Cytotoxic and apoptotic effects of six herbal plants against the human hepatocarcinoma (HepG2) cell line. Chin. Med. 2011, 6, 39. [CrossRef] [PubMed]

67. Prayong, P.; Barusrux, S.; Weerapreeyakul, N. Cytotoxic activity screening of some indigenous Thai plants. Fitoterapia 2008, 79, 598-601. [CrossRef]

68. Sun, J.; Yu, X.; Xue, L.; Li, S.; Li, J.; Tong, D.; Du, Y. TP53-Associated Ion Channel Genes Serve as Prognostic Predictor and Therapeutic Targets in Head and Neck Squamous Cell Carcinoma. Technol. Cancer Res. Treat. 2020, 19, 1533033820972344. [CrossRef] [PubMed]

69. Zhou, G.; Liu, Z.; Myers, J.N. TP53 Mutations in Head and Neck Squamous Cell Carcinoma and Their Impact on Disease Progression and Treatment Response. J. Cell. Biochem. 2016, 117, 2682-2692. [CrossRef] [PubMed]

70. Bostan, M.; Petrica-Matei, G.G.; Ion, G.; Radu, N.; Mihaila, M.; Hainarosie, R.; Brasoveanu, L.I.; Roman, V.; Constantin, C.; Neagu, M.T. Cisplatin effect on head and neck squamous cell carcinoma cells is modulated by ERK1/2 protein kinases. Exp. Ther. Med. 2019, 18, 5041-5051. [CrossRef]

71. Zeng, W.; Sun, H.; Meng, F. Nuclear C-MYC expression level is associated with disease progression and potentially predictive of two year overall survival in prostate cancer. Int. J. Clin. Exp. Pathol. 2015, 8, 1878-1888. [PubMed]

72. $\quad$ Lin, S.H.; Wang, S.K.; Yeh, K.T.; Tai, H.C.; Wang, H.Y.; Huang, L.R.; Chiu, C.E.; Chung, C.M.; Velmurugan, B.K. c-MYC expression in T (III/IV) stage oral squamous cell carcinoma (OSCC) patients. Cancer Manag. Res. 2019, 11, 5163-5169. [CrossRef] [PubMed]

73. Brockmueller, A.; Sameri, S.; Liskova, A.; Zhai, K.; Varghese, E.; Samuel, S.M.; Büsselberg, D.; Kubatka, P.; Shakibaei, M. Resveratrol's Anti-Cancer Effects through the Modulation of Tumor Glucose Metabolism. Cancers 2021, 13, 188. [CrossRef]

74. Petrica-Matei, G.G.; Iordache, F.; Hainarosie, R.; Bostan, M. Characterization of the tumor cells from human head and neck cancer. Rom. J. Morphol. Embryol. 2016, 57, 791-799. [PubMed]

75. Radu, N.; Roman, V.; Bostan, M.; Radu, E.; Tanasescu, C. Influence of some spice food based bioproducts on human monocytic cells line type THP-1. Mol. Cryst. Liq. Cryst. 2017, 655, 114-123. [CrossRef] 
76. Iancu, I.V.; Botezatu, A.; Plesa, A.; Huica, I.; Fudulu, A.; Albulescu, A.; Bostan, M.; Mihaila, M.; Grancea, C.; Manda, D.; et al. Alterations of regulatory factors and DNA methylation pattern in thyroid cancer. Cancer Biomark. Sect. A Dis. Markers 2020, 28, 1-14. [CrossRef]

77. Botezatu, A.; Iancu, I.V.; Plesa, A.; Manda, D.; Popa, O.; Bostan, M.; Mihaila, M.; Albulescu, A.; Fudulu, A.; Vladoiu, S.V.; et al. Methylation of tumour suppressor genes associated with thyroid cancer. Cancer Biomark. 2019, 25, 53-65. [CrossRef] [PubMed]

78. Maciuca, A.M.; Munteanu, A.C.; Mihaila, M.; Badea, M.; Olar, R.; Nitulescu, G.M.; Munteanu, C.V.A.; Bostan, M.; Uivarosi, V. Rare-Earth Metal Complexes of the Antibacterial Drug Oxolinic Acid: Synthesis, Characterization, DNA/Protein Binding and Cytotoxicity Studies. Molecules 2020, 25, 5418. [CrossRef] [PubMed]

79. Zarafu, I.; Matei, L.; Bleotu, C.; Ionita, P.; Tatibouët, A.; Paun, A.; Nicolau, I.; Hanganu, A.; Limban, C.; Nuta, D.C.; et al. Synthesis, Characterization, and Biologic Activity of New Acyl Hydrazides and 1,3,4-Oxadiazole Derivatives. Molecules 2020, $25,3308$. [CrossRef] 